IF. Sér. Reg. n. 55 p. $29-73$ dezembro 2017

http://dx.doi.org/10.4322/ifsr.2018.002

ISSN on-line 2179-2372

\title{
DIAGNÓSTICO E PROPOSTAS DE MANEJO DA VEGETAÇÃO DA ESTAÇÃO ECOLÓGICA DE MARÍLIA, SP, SUDESTE DO BRASIL ${ }^{1}$
}

\section{DIAGNOSIS AND VEGETATION MANAGEMENT PROPOSALS OF MARÍLIA ECOLOGICAL STATION, SP, SOUTHEASTERN BRAZIL}

\author{
Natália Macedo IVANAUSKAS ${ }^{2,3}$; Geraldo Antonio Daher Corrêa. FRANCO²; Giselda DURIGAN²; \\ Isabel Fernandes de Aguiar MATTOS²; Maria Teresa Zugliani TONIATO²; Marina Mitsue KANASHIRO²; \\ Natashi Aparecida de Lima PILON²; Renata Giassi UDULUTSCH ${ }^{3}$
}

\begin{abstract}
RESUMO Este estudo apresenta o diagnóstico da vegetação elaborado para embasar o plano de manejo da Estação Ecológica de Marília, Unidade de Conservação de Proteção Integral que ocupa 604 ha e conserva os maiores fragmentos de vegetação nativa do município de Marília, SP. A caracterização da vegetação foi baseada na interpretação de fotografias aéreas e levantamento de campo, no qual foram observados atributos da estrutura da vegetação e a composição de espécies em trilhas com diferentes graus de conservação. Também foi realizado levantamento das pesquisas realizadas na unidade e das coletas de espécies vegetais registradas nas coleções biológicas disponíveis on-line. Atualmente a vegetação nativa recobre 66\% e os reflorestamentos com exóticas (Pinus sp. e eucalipto) ocupam 23\% da área total. Predomina a Floresta Estacional Semidecidual, nas categorias Montana e Aluvial. A flora da unidade totalizou 277 espécies nativas, pertencentes a 185 gêneros e 73 famílias. Oito espécies constam em uma ou mais listas de espécies ameaçadas de extinção. As famílias mais ricas em espécies foram Fabaceae (40 espécies), Bignoniaceae (30) e Myrtaceae (18), refletindo o maior esforço de coleta entre espécies arbóreas (Fabaceae e Myrtaceae) e trepadeiras (Bignoniaceae). Foram registradas 16 espécies exóticas presentes em áreas naturais, das quais cinco consideradas invasoras. A proposta de zoneamento contemplou $41 \%$ da área como zona primitiva e $58 \%$ como zona de recuperação, sendo esta delimitada em três subzonas, devido aos diferentes graus de interferência humana e às necessidades específicas de manejo para o reestabelecimento dos processos naturais de sucessão secundária e recuperação dos ecossistemas.
\end{abstract}

Palavras-chave: flora, unidade de conservação, zoneamento, Floresta Estacional Semidecidual.

\begin{abstract}
The objective of this study was to characterize the vegetation of Marília Ecological Station in order to offer subsidies to its management plan. This integral protection conservation unit occupies 604 hectares and retains the largest fragments of native vegetation at the Marília municipality, SP. The vegetation assessment was conducted based on a map generated by photointerpretation and field surveys, in which attributes of vegetation structure and species composition were recorded. Additionally, surveys were
\end{abstract}

\footnotetext{
${ }^{1}$ Artigo científico. Recebido para análise em 19.10.2016. Aceito para publicação em 09.05.2017.

${ }^{2}$ Instituto Florestal, Rua do Horto, 931, CEP: 02377-000, Horto Florestal, São Paulo, SP, Brasil.

3Universidade Estadual Paulista "Júlio de Mesquita Filho", Av. Dom Antonio, 2.100, CEP:19806-173, Assis, SP, Brasil.

${ }^{4}$ Autor para correspondência: Natália Macedo Ivanauskas -: nivanaus@yahoo.com.br
} 
done on studies conducted in the Ecological Station, as well as on plant species recorded in biological collections available online. Currently native vegetation covered $66 \%$ and exotic species reforestation (Pinus sp. and eucalipto) occupied $23 \%$ of the total area. Seasonal Semideciduous Forest was the most widespread vegetation type, with fragments grouped into Montana and Alluvial categories. A total of 277 native species, belonging to 185 genera and 73 families, were identified. Eight species are included in one or more endangered species lists. The richest families were Fabaceae (40 species), Bignoniaceae (30) and Myrtaceae (18), which was explicated by substantial collecting effort of tree (Fabaceae and Myrtaceae) and vines (Bignoniaceae) species. Sixteen exotic species were identified, of which five were considered dominant invader. In the context of the management plan, it was proposed that $41 \%$ of the Ecological Station be assigned to the primitive zone, and $58 \%$ be designated as recovery zone, with three subareas, based on the different degrees of human influence over the environment and ensuring the reestablishment of secondary succession process and restoration of ecosystems.

Keywords: flora, conservation unit, zoning, Seasonal Semideciduous Forest.

\section{INTRODUÇÃO}

A região de Marília situa-se na região Oeste do Estado de São Paulo, onde predomina a Floresta Estacional Semidecidual, mas também há encraves de formações savânicas. As florestas estacionais foram pouco estudadas antes de sua destruição em larga escala, de maneira que sabemos muito pouco sobre sua composição florística primitiva (Galindo-Leal e Câmara, 2005). Mesmo assim, a região é reconhecida como área de alto endemismo e diversidade, tanto na região tropical ou subtropical como globalmente (Bibby et al., 1992; Laclau, 1994).

O município de Marília apresenta poucos fragmentos de vegetação nativa. Em 2005, os remanescentes de vegetação natural ocupavam 13.583 ha - ou 13,6\% da área do município (Nalon et al., 2009), a maior parte com área inferior a dez hectares (Kronka et al., 2005), o que os torna quase na sua totalidade sob efeito de borda, com baixa estrutura, baixa diversidade e dominados por espécies pioneiras. A Estação Ecológica de Marília apresenta 604,14 ha, portanto é um dos maiores fragmentos de Floresta Estacional Semidecidual do município.

Um dos grandes desafios para os gestores de uma unidade de conservação (UC) de proteção integral é como conservar a biodiversidade existente em um cenário de ambientes naturais muito fragmentados e sujeitos a fortes pressões antrópicas (Kotchetkoff-Henriques, 2003). Nesse contexto, a Lei 9.985 de 15/07/2000, que instituiu o Sistema Nacional de Unidades de Conservação da Natureza - SNUC (Brasil, 2000), determina que cada UC tenha seu próprio Plano de Manejo, definido como um “... documento técnico mediante o qual, com fundamento nos objetivos gerais de uma Unidade de Conservação, se estabelece o seu zoneamento e as normas que devem presidir o uso da área e o manejo dos recursos naturais".

Os levantamentos de vegetação são componentes fundamentais na execução de planos de manejo, pois é atribuído a esse tema a etapa de mapeamento e caracterização inicial da paisagem, que resulta na definição dos locais de amostragem para as equipes de flora e fauna (Keel et al., 2003). Além disso, a caracterização da vegetação é de extrema importância para as decisões a serem tomadas nos Programas de Manejo. A equipe de vegetação identifica e mapeia os tipos vegetacionais, produz estimativas de diversidade das plantas e caracteriza as espécies de interesse. Essas informações podem ser usadas para priorizar sítios e definir estratégias de manejo em uma Unidade de Conservação, abordando zonas potenciais para os diferentes usos definidos pelo Sistema Nacional de Unidades de Conservação - SNUC (pesquisa, educação ambiental e turismo ecológico) e de áreas com características relevantes para proteção.

Nesse contexto, este documento apresenta o diagnóstico da vegetação, que integra o módulo “Avaliação da biodiversidade" do Plano de Manejo da Estação Ecológica de Marília, Marília - SP. 
IVANAUSKAS N. M.. et al. Diagnóstico e Propostas de Manejo da Vegetação da Estação Ecológica de Marília, SP, Sudeste do Brasil.

\section{MATERIAL E MÉTODOS}

\section{1 Área de estudo}

A Estação Ecológica de Marília foi criada em 28 de dezembro de 2010 (São Paulo, 2010), com 607,14 ha, no município de Marília, tendo como coordenadas de referência $22^{\circ} 01^{\prime} \mathrm{S}$ e $49^{\circ} 55^{\prime} \mathrm{W}$ e $400 \mathrm{~m}$ de altitude (Figura 1). A área corresponde à outrora Estação Experimental de Marília, criada em 1964, quando da desapropriação de uma gleba para fins de reforma agrária (Durigan e Leitão Filho, 1995).

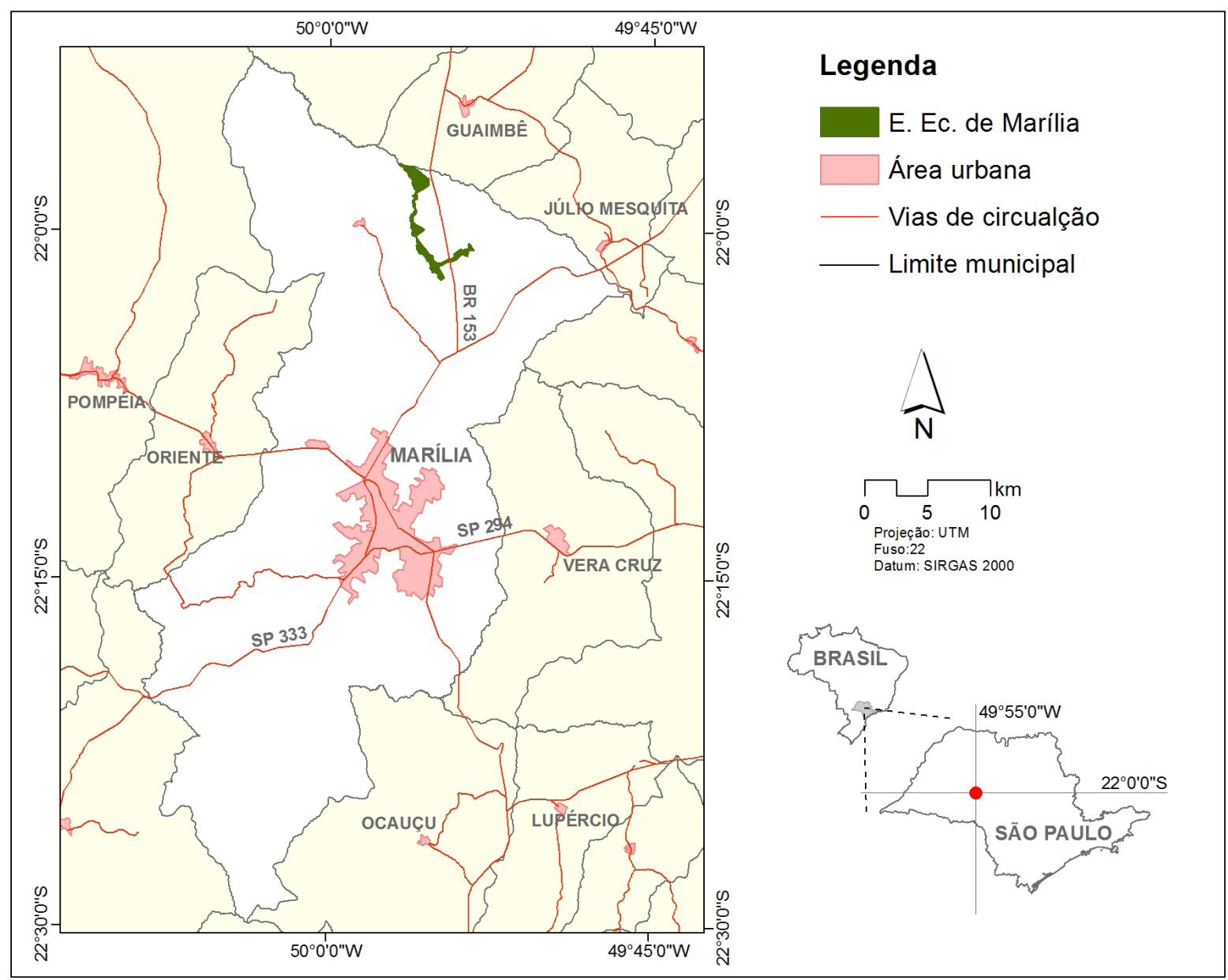

Figura 1. Localização da Estação Ecológica de Marília, município de Marília, SP

Figure 1. Location of the Marília Ecological Station, Marília municipality, SP.

No sistema de classificação climática de Köppen (Alvares et.al., 2013), o clima de Marília é do tipo Aw, portanto tropical, árido e acentuadamente sazonal, com período de seca no inverno. O mês mais frio apresenta temperatura média superior a $18^{\circ} \mathrm{C}$, o mês mais seco tem precipitação inferior a $60 \mathrm{~mm}$ e o período chuvoso se atrasa para o outono (Miranda et al., 2014). As médias anuais para o município são as seguintes: precipitação total de $1.428 \mathrm{~mm}$, temperatura média de $23,5^{\circ} \mathrm{C}$, com mínima de $17,3^{\circ} \mathrm{C}$ e máxima de $29,5^{\circ} \mathrm{C}$ (CEPAGRI, 2014). 


\subsection{Mapeamento da vegetação}

Para o mapeamento da vegetação foram adaptados os procedimentos descritos em Mattos (1994), com o uso de fotografias aéreas digitais, escala 1:30.000, do ano de 2005, da Base Aerofotogrametria e Projetos S.A. A análise das fotografias foi realizada com base nos procedimentos recomendados por Lueder (1959) e Spurr (1960), nos quais a vegetação é classificada por meio do uso de elementos da imagem fotográfica, como cor, tonalidade e textura. As informações obtidas foram então espacializadas sobre as cartas topográficas digitais do IBGE (1983), escala 1:50.000, elaborando-se um mapa preliminar.

Durante o trabalho de campo, realizado em janeiro de 2013, os padrões obtidos nas imagens foram verificados e corrigidos (quando necessário) para a elaboração do mapa final. O sistema de classificação da vegetação adotado foi o proposto por Veloso (1992) e adaptado ao revisado pelo IBGE (2012).

\subsection{Caracterização da flora}

Ainda na etapa de levantamentos de campo, foi elaborada uma lista expedita de espécies da flora, com o intuito de auxiliar no reconhecimento dos tipos vegetacionais existentes na unidade. Foram feitos caminhamentos no entorno dos fragmentos de vegetação natural e incursões aleatórias ao interior dessas áreas, a partir de trilhas pré-existentes (Tabela 1, Figura 2). Ao longo do caminho foram amostrados predominantemente os indivíduos arbustivos, arbóreos e as trepadeiras. O material botânico coletado foi identificado por meio de comparação com exsicatas depositadas em herbários, com o uso de bibliografia específica ou por consulta a especialistas. Após a identificação, o material fértil foi incorporado ao herbário Dom Bento Pickel, do Instituto Florestal (SPSF).

Para complementar essa informação e, portanto, melhor caracterizar a riqueza de espécies, foram acrescidos a essa listagem os registros secundários. Foram consultados estudos florísticos e fitossociológicos já desenvolvidos na Estação, incluindo-se artigos científicos, dissertações e teses. Também foram incluídos os registros informatizados das exsicatas depositadas em herbários e disponíveis nas bases de dados INCT - Herbário Virtual da Flora e dos Fungos (2014). Os dados foram obtidos diretamente no material impresso ou online, não tendo sido feita a verificação do material testemunho. Apenas as identificações com binômio completo foram consideradas.

Para a inclusão das citações provenientes dos registros de herbários, foram utilizados também os seguintes critérios: a) exsicatas certamente registradas dentro dos limites da unidade (coletas com coordenadas geográficas); b) registros de que a coleta havia sido realizada em Marília-SP e que continham, em algum dos campos (ex.: localidade e notas), informações adicionais como "Estação Experimental de Marília", "E.E. Marília" ou "Instituto Florestal". Materiais duplicados foram reconhecidos pelo mesmo número do coletor em herbários distintos. Nesses casos, somente um material foi escolhido e considerado. Se encontrada mais de uma exsicata de uma mesma espécie, foi selecionada aquela com a data de coleta mais recente.

A lista final de espécies, resultante da união dos dados primários e secundários, seguiu a grafia e as sinonímias botânicas conforme a Lista de Espécies da Flora do Brasil (Forzza et al., 2014). A classificação das famílias foi baseada em APG IV (2016).

A partir da lista das espécies registradas na área de estudo foram destacadas aquelas consideradas ameaçadas e exóticas. As listas oficiais das espécies vegetais ameaçadas de extinção utilizadas para consulta foram: a) Lista oficial de espécies ameaçadas de extinção no estado de São Paulo (São Paulo, 2016); b) Livro Vermelho da Flora do Brasil (Martinelli e Moraes, 2013) e a Lista de espécies da flora do Brasil (Forzza et al., 2014); c) Lista vermelha de espécies ameaçadas de extinção globalmente (IUCN, 2014).

Foram consideradas como espécies exóticas aquelas de ocorrência fora dos limites geográficos historicamente reconhecidos e como exóticas invasoras quando estas ameaçam habitats, ecossistemas ou outras espécies, pois passam a dispersar-se e exercer dominância sobre ambientes naturais (Ziller, 2001). 
IVANAUSKAS N. M.. et al. Diagnóstico e Propostas de Manejo da Vegetação da Estação Ecológica de Marília, SP, Sudeste do Brasil.

Foram consideradas exóticas invasoras aquelas registradas no sistema de informação da rede I3N Brasil (Instituto Hórus, 2014). Para avaliar a situação da invasão foram utilizadas as seguintes classes (Zalba, 2005): 1. presente: encontrada em ambiente natural, porém ainda sem descendência ou dispersão aparente; 2. estabelecida: quando está se reproduzindo localmente, com descendência; 3 . invasora: quando se expande a partir do ponto inicial e está em processo de dispersão.

Espécies-problema foram definidas como aquelas nativas e/ou exóticas que formam populações fora de sua característica típica ou fora de seu tamanho desejável (Moreira e Piovezan, 2005). A primeira situação trata da necessidade de controle de uma população que apresenta explosão em densidade ou biomassa e, portanto, encontra-se fora de sua estabilidade natural. Em sua maior parte, as espécies nativas causam problemas desse tipo e a ação de manejo necessária é temporária, pois visa apenas restabelecer o estado normal desta população. Já a segunda situação se refere às populações que, mesmo em seu estado típico, não são desejáveis num determinado local e exigem manejo contínuo, situação que é frequente entre as espécies exóticas que invadem áreas naturais.

\subsection{Critérios para o zoneamento}

As fisionomias vegetais mapeadas na Estação Ecológica de Marília foram avaliadas qualitativamente quanto ao grau de conhecimento da flora (médio, baixo e nulo) e a sua prioridade para a pesquisa (alta, média e baixa). Para essa qualificação, considerou-se a existência ou não de dados primários e/ou secundários sobre a flora da Estação em cada fisionomia.

O mapa de áreas prioritárias para a conservação baseou-se na análise qualitativa do estado de conservação dos trechos mapeados e verificados em campo, nos vetores de degradação, na composição de espécies e na importância de cada fisionomia na paisagem regional. Em função da variação na composição florística, dos gradientes e de diferenças no esforço amostral empregado em cada trecho, a riqueza de espécies não foi considerada, isoladamente, como parâmetro importante na categorização dos trechos amostrados. O grau de conservação da área e a presença de espécies ameaçadas foram os indicadores de maior peso para a classificação final. Foram consideradas as seguintes categorias:

Extrema (4): trechos com elevado número de espécies endêmicas, ameaçadas ou raras. Existência de hábitats ou fenômenos naturais únicos. Maior grau de conservação da vegetação quando comparada a outras áreas. Área com vocação para a preservação.

Alta (3): Vegetação em bom estado de conservação, com presença de espécies ameaçadas, raras ou endêmicas. Se encontradas, espécies exóticas pouco abundantes. Vocação para a conservação e pesquisa ou atividades educativas de impacto mínimo.

Média (2): Vegetação secundária. Se encontradas, poucas espécies endêmicas, ameaçadas ou raras, cujas populações possam tolerar certas intervenções, como o uso público extensivo ou intensivo.

Baixa (1): Baixa riqueza de espécies nativas. Alto grau de intervenção e riqueza ou abundância de espécies exóticas. Áreas antropizadas.

A proposta para o zoneamento da Estação Ecológica foi elaborada conforme conceitos estabelecidos no roteiro metodológico do IBAMA (Galante et al., 2002) e levou em consideração apenas os aspectos relativos à vegetação nativa remanescente da Estação Ecológica. Baseou-se, portanto, em critérios estritamente conservacionistas e não contemplou os outros usos aos quais as áreas estão ou têm potencial para serem destinadas. Assim, foram consideradas apenas as zonas diretamente relacionadas à conservação da vegetação natural, sendo estas as zonas intangível, primitiva e de recuperação. A delimitação das demais zonas foi definida com base nas propostas das demais equipes envolvidas no Plano de Manejo.

A delimitação das manchas no mapa do zoneamento sofreu ajustes para uniformizar as zonas, evitando-se a permanência de manchas muito pequenas de uma zona em meio à outra, o que não faria sentido do ponto de vista do manejo. 
IVANAUSKAS N. M.. et al. Diagnóstico e Propostas de Manejo da Vegetação da Estação Ecológica de Marília, SP, Sudeste do Brasil.

Tabela 1. Pontos amostrados na Avaliação Ecológica Rápida realizada Estação Ecológica de Marília, Marília - SP. Coordenadas dos pontos também apresentados na Figura 1.

Table 1. Points sampled during the Rapid Ecological Assessment carried out at the Marília Ecological Station, Marília - SP. The coordinates of the points also shown in Figure 1.

\begin{tabular}{|c|c|c|c|c|}
\hline \multirow[b]{2}{*}{ Base } & \multirow[b]{2}{*}{ Ponto } & \multicolumn{3}{|c|}{ Coordenadas (UTM, SAD 69, Zona 22K) } \\
\hline & & $\mathrm{x}$ & $\mathrm{y}$ & $\mathrm{z}(\mathrm{m})$ \\
\hline \multirow[t]{6}{*}{ Córrego Sta Helena/Viveiro } & 1 & 614262 & 7564880 & 435 \\
\hline & 2 & 614235 & 7565013 & 440 \\
\hline & 3 & 614652 & 7565314 & 461 \\
\hline & 4 & 614341 & 7565786 & 463 \\
\hline & 5 & 614355 & 7565682 & 463 \\
\hline & 6 & 614421 & 7565659 & 462 \\
\hline \multirow[t]{7}{*}{ Pomar/Carvoeiro } & 7 & 612183 & 7563645 & 445 \\
\hline & 8 & 612386 & 7563101 & 439 \\
\hline & 9 & 612166 & 7562965 & 413 \\
\hline & 10 & 612229 & 7563010 & 423 \\
\hline & 11 & 612165 & 7563430 & 440 \\
\hline & 12 & 612124 & 7563394 & 436 \\
\hline & 13 & 611957 & 7563871 & 428 \\
\hline \multirow[t]{8}{*}{ Cachoeirinha } & 14 & 611687 & 7564334 & 438 \\
\hline & 15 & 611436 & 7564868 & 418 \\
\hline & 16 & 611034 & 7565202 & 444 \\
\hline & 17 & 611659 & 7564355 & 452 \\
\hline & 18 & 611583 & 7564434 & 449 \\
\hline & 19 & 611455 & 7564835 & 418 \\
\hline & 20 & 611419 & 7564885 & 419 \\
\hline & 21 & 611034 & 7565200 & 443 \\
\hline \multirow[t]{4}{*}{ Ponto 80} & 22 & 612296 & 7564254 & 416 \\
\hline & 23 & 610616 & 7567079 & 452 \\
\hline & 24 & 610272 & 7566201 & 413 \\
\hline & 25 & 610082 & 7267372 & 433 \\
\hline \multirow[t]{13}{*}{ Pádua Sales } & 26 & 611146 & 7570679 & 454 \\
\hline & 27 & 610371 & 7570996 & 436 \\
\hline & 28 & 610103 & 7571463 & 422 \\
\hline & 29 & 610215 & 7571698 & 407 \\
\hline & 30 & 610355 & 7570968 & 434 \\
\hline & 31 & 610642 & 7570260 & 440 \\
\hline & 32 & 610280 & 7569988 & 411 \\
\hline & 33 & 610359 & 7569970 & 416 \\
\hline & 34 & 610219 & 7569857 & 409 \\
\hline & 35 & 610138 & 7571164 & 428 \\
\hline & 36 & 609966 & 7571707 & 416 \\
\hline & 37 & 610123 & 7571191 & 430 \\
\hline & 38 & 610111 & 7571778 & 406 \\
\hline
\end{tabular}


IVANAUSKAS N. M.. et al. Diagnóstico e Propostas de Manejo da Vegetação da Estação Ecológica de Marília, SP, Sudeste do Brasil.

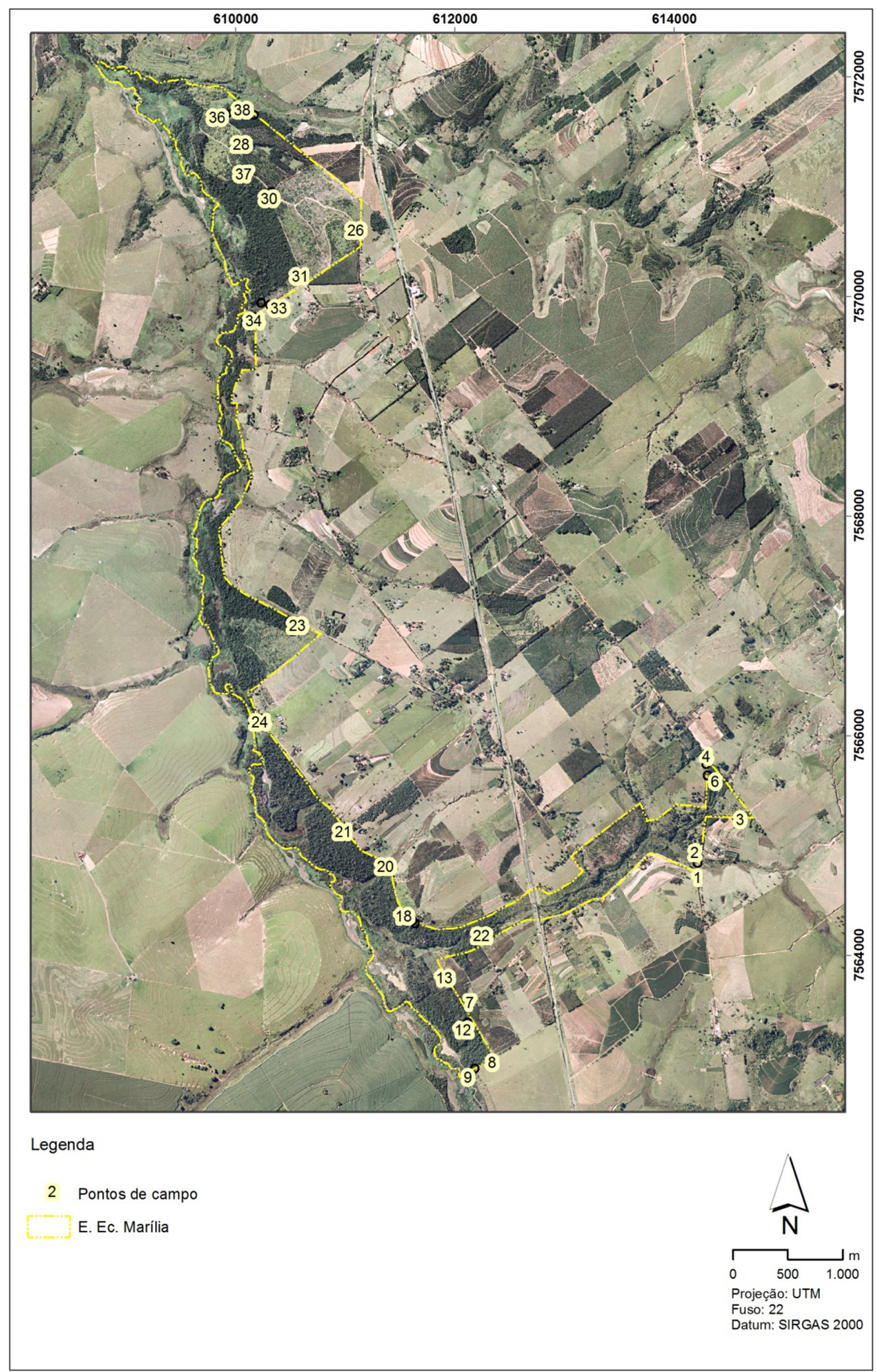

Figura 2. Pontos amostrados na Avaliação Ecológica Rápida realizada Estação Ecológica de Marília, Marília - SP. Coordenadas dos pontos também apresentados na Tabela 1.

Figure 2. Points sampled during the Rapid Ecological Assessment carried out at the Marília Ecological Station, Marília SP. The coordinates of the points also shown in Table 1. 


\section{RESULTADOS E DISCUSSÃO}

\subsection{Formações naturais presentes na Estação Ecológica de Marília}

A Estação Ecológica de Marília está presente em área de ocorrência de domínio da Mata Atlântica (Ab'Sáber, 2003), no interior paulista, em região onde predomina a Floresta Estacional Semidecidual (IBGE, 2012).

O primeiro mapeamento da vegetação da Estação Ecológica de Marília data de 1973 (Figura 3) e foi realizado com foco nos talhões de reflorestamento com espécies exóticas (Pinus sp., Corymbia sp. e Eucalyptus sp.). No entanto, as formações naturais presentes àquela época também foram incluídas, distribuídas nas categorias Mata e Banhado. Há ainda uma categoria denominada Bosque, termo que se supõe tratar de uma mata degradada (bosqueada). Infelizmente, não foi possível recuperar a área ocupada com vegetação nativa, mas os talhões com reflorestamentos de exóticas apresentados somam 136,61 ha (23\% da área total, Figura 2). Atualmente, os reflorestamentos com espécies exóticas ocupam 135,99 ha (22\% da área total, Tabela 2, Figura 4). Portanto, praticamente não houve alteração no percentual da área ocupada com sistemas de produção, mas pode-se notar a expansão das florestas nativas comparando-se os seus limites nos mapeamentos de 1973 (Figura 3) e 2014 (Figura 4).

Atualmente a vegetação nativa recobre 400,22 ha, o que representa $66 \%$ em área desta unidade de proteção integral (Tabela 2, Figura 4). Predomina a Floresta Estacional Semidecidual, subdividida de acordo com o sistema de Veloso (1992) em faixas altimétricas. Assim, nas áreas de interflúvio ocorre a Floresta Estacional Semidecidual Montana e, ao longo dos cursos d'água, a Floresta Estacional Semidecidual Aluvial (Figura 4, Tabela 2).

A Floresta Estacional Semidecidual Montana ocupa 167,07 hectares (28\% da área total). Essa formação é caracterizada por apresentar dossel não perfeitamente contínuo (irregular), entre 15 e $20 \mathrm{~m}$ de altura, com presença de árvores emergentes de até 25-30 m de altura. A estratificação da comunidade não ultrapassa três camadas ou não é perceptível. Abaixo do estrato superior há um sub-bosque arbóreo-arbustivo bastante denso e, sob este, estrato herbáceo ralo. Os troncos das árvores são frequentemente perfilhados e as copas revelam-se amplas, ralas e esgalhadas e com gemas foliares protegidas do estresse hídrico por catáfilos ou tricomas (Veloso e Góes-Filho, 1982). Ervas macrófilas, fetos, palmeiras e epífitas são escassos, devido à baixa umidade do ar.

A Floresta Estacional Semidecidual Montana presente na Estação Ecológica foi subdividida em três fitofisionomias (Fm1, Fm2 e Fm3), de acordo como seu estádio de conservação (Figura 4). Predominam trechos de floresta com árvores de porte médio a alto compondo dossel fechado, denso, mas ainda com sinais de alteração (Fm1). Esses trechos haviam sido mapeados como "Mata" em 1973 e compõem parte dos trechos florestais mais preservados da unidade. As demais florestas de interflúvio (Fm2 e Fm3) também coincidem com as áreas de "Mata" em 1973, mas apresentam dossel de porte médio a baixo, diferenciando-se pelo maior grau de alteração. Além do extrativismo seletivo e do processo de fragmentação a que esses remanescentes foram historicamente submetidos, a ocorrência de incêndios é apontada como o principal vetor de degradação a que essas áreas foram sujeitas (Figura 5).

Durigan e Leitão Filho (1995) realizaram inventário florístico e fitossociológico em um fragmento de Floresta Estacional Semidecidual com área total de 154,80 ha, às margens do córrego Santa Helena, canal secundário do rio Aguapeí (Horton, 1940). Segundo os autores, a faixa de floresta ao longo dos rios Tibiriçá e Santa Helena, mantida como reserva da antiga Estação Experimental de Marília, sofreu exploração de madeiras nobres, como a peroba (Aspidosperma polyneuron) e o ipê-roxo (Handroanthus heptaphyllus), entre outras. Na ocasião das expedições, os autores descreveram o fragmento dominado por trepadeiras, que proliferaram em decorrência de perturbações antrópicas e que dificultavam a regeneração natural. 
IVANAUSKAS N. M.. et al. Diagnóstico e Propostas de Manejo da Vegetação da Estação Ecológica de Marília, SP, Sudeste do Brasil.

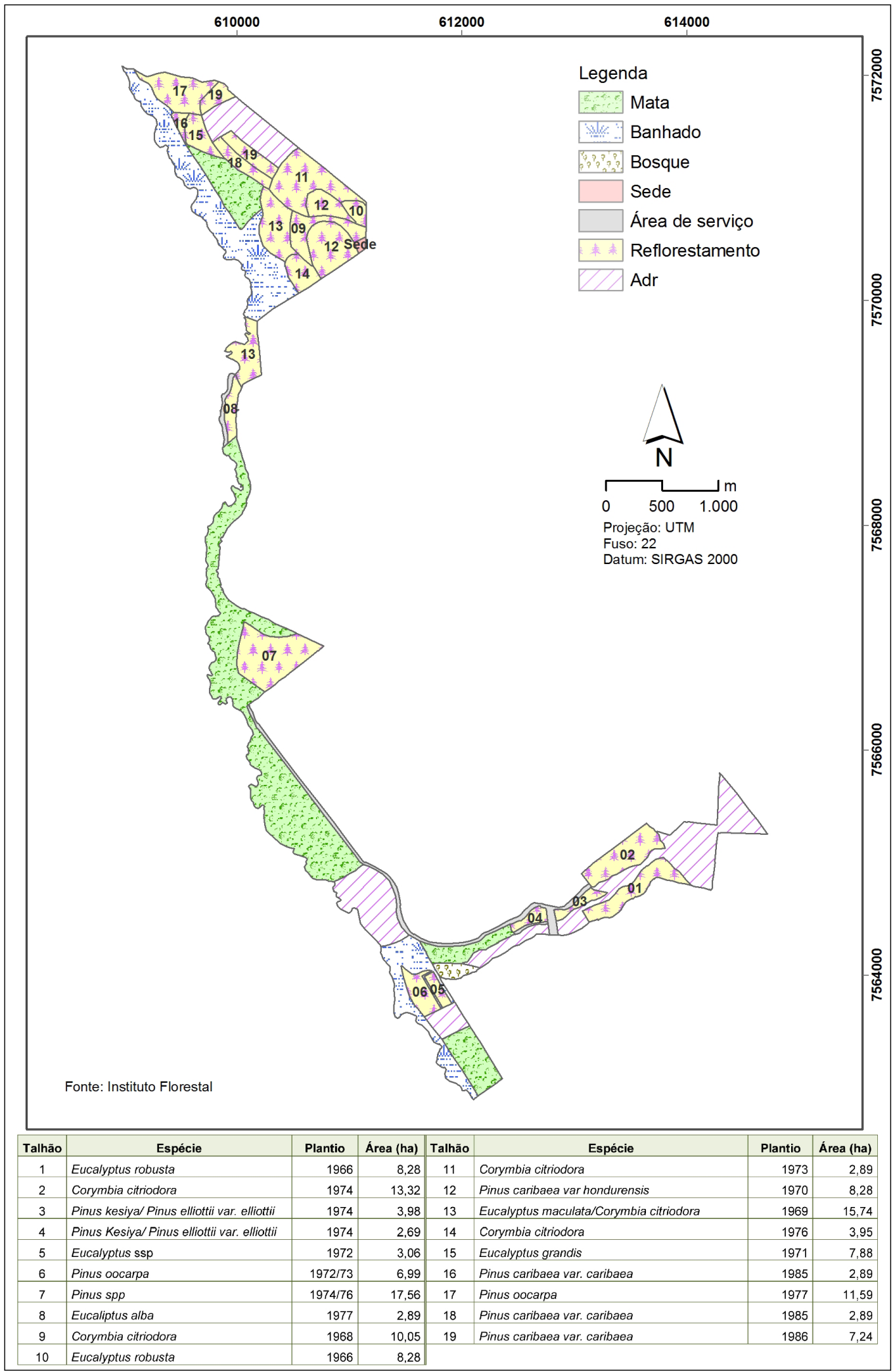

Figura 3. Vegetação da Estação Ecológica de Marília em 1973, com destaque para os talhões de plantios de espécies exóticas (Pinus, Corymbia e Eucalyptus) e áreas com vegetação nativa (mata e banhado).

Figure 3. Vegetation types recognized in the Marília Ecological Station in 1973, highlighting the exotic species plantations plots (Pinus, Eucalyptus and Corymbia) and native vegetation areas (forest and wetland). 
IVANAUSKAS N. M.. et al. Diagnóstico e Propostas de Manejo da Vegetação da Estação Ecológica de Marília, SP, Sudeste do Brasil.

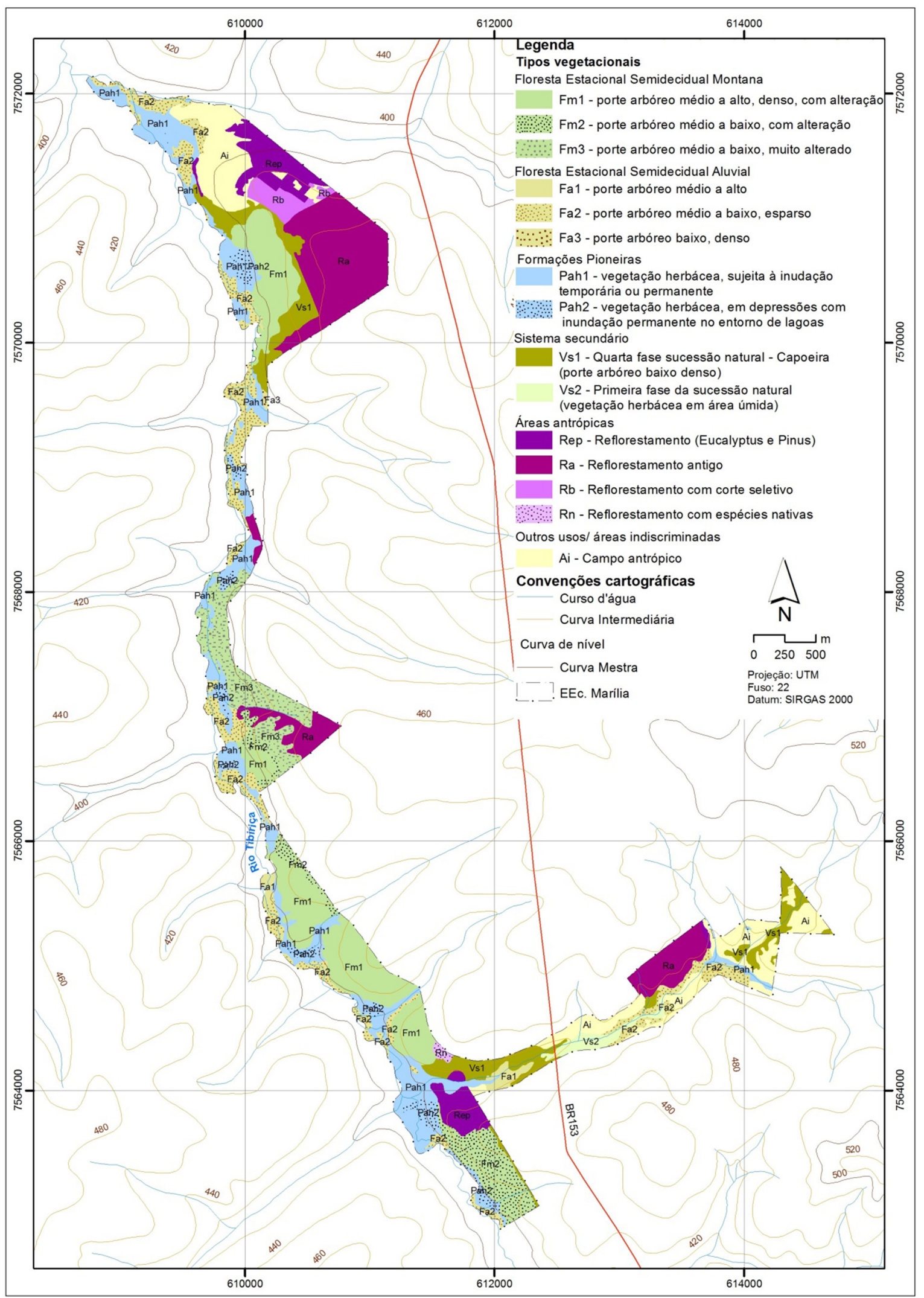

Figura 4. Fitofisionomias da Estação Ecológica de Marília, Marília- SP. Os códigos correspondem às categorias da Tabela 2.

Figure 4. Phytophysiognomies of Marília Ecological Station, Marília-SP. The codes correspond to the categories shown in Table 2. 
IVANAUSKAS N. M.. et al. Diagnóstico e Propostas de Manejo da Vegetação da Estação Ecológica de Marília, SP, Sudeste do Brasil.

Tabela 2. Tipos vegetacionais mapeados na Estação Ecológica de Marília, Marília-SP.

Table 2. Vegetation types mapped at the Marília Ecological Station, Marília-SP.

\begin{tabular}{lcc}
\hline Tipos de Vegetação Natural & Área (ha) & Área (\%) \\
\hline Floresta Estacional Semidecidual Montana (Fm) & & 16 \\
Fm1 - porte arbóreo médio a alto, denso, com alteração & 94,96 & 6 \\
Fm2 - porte arbóreo médio a baixo, com alteração & 34,75 & 6 \\
Fm3 - porte arbóreo médio a baixo, muito alterado & 37,36 & \\
Floresta Estacional Semidecidual Aluvial (Fa) & & 1 \\
Fa1 - porte arbóreo médio a alto & 6,09 & 12 \\
Fa2 - porte arbóreo médio a baixo, esparso & 70,26 & 0 \\
Fa3 - porte arbóreo baixo, denso & 0,58 & \\
Formações Pioneiras & & 13 \\
Vegetação com influência fluvial e/ou lacustre (Pa) & & 3 \\
Pah1 - vegetação herbácea, sujeita à inundação temporária ou permanente & 81,50 \\
Pah2 - vegetação herbácea, em depressões com inundação permanente no entorno de & 18,99 & \\
lagoas & & \\
Áreas antrópicas & & \\
Sistema secundário (Vs) & & \\
Vs1 - Quarta fase da sucessão natural - Capoeira (porte arbóreo baixo denso) & 48,01 \\
Vs2 - Primeira fase da sucessão natural (vegetação herbácea em área úmida) & 7,72 \\
Reflorestamento (R) & & 1 \\
Rep - Reflorestamento (Eucalipto e Pinus) & 34,00 & 6 \\
Ra - Reflorestamento antigo & 92,29 & 15 \\
Rb - Reflorestamento com corte seletivo & 9,70 \\
Rn - Reflorestamento com espécies nativas & 1,46 & 2 \\
Outros usos/áreas indiscriminadas (Ai) & & 0 \\
Ai - Campo antrópico & 69,22 \\
Total & $\mathbf{6 0 6 , 8 9}$ & $\mathbf{1 0 0}$ \\
\hline
\end{tabular}

Por definição, a Floresta Estacional Semidecidual Aluvial está presente na margem ou muito próxima dos cursos d'água (Figura 4). Em 2013, ocupava 76,93 ha da Estação Ecológica (13\% da área total, Tabela 2), inclusive áreas consideradas como Banhado no mapeamento de 1973 (Figura 3). Nesse contexto, não se pode descartar a influência das variações do Rio Tibiriçá na dinâmica dessas vegetações de várzea, alterando o mosaico entre formações pioneiras e florestas aluviais.

As florestas aluviais, comparadas àquelas de interflúvio, apresentam maior perenidade foliar, em função da maior disponibilidade de água proveniente do lençol freático elevado e dos pulsos de inundação, conforme observado na Estação Experimental de Marília (Durigan et al. 1996; Durigan e Pagano, 2000). Esses trechos de floresta ciliar são os que se encontram melhor preservados, com árvores de grande porte (15$20 \mathrm{~m}$ ) e menor quantidade de trepadeiras. Assim como já observado na Estação Ecológica de Ribeirão Preto (Ivanauskas et al., 2011), a maior disponibilidade hídrica nesses locais deve propiciar menor deciduidade, o que contribui para a menor proliferação de trepadeiras, que dependem de luz para o seu desenvolvimento.

Da mesma forma, eventuais incêndios podem não ter atingido essas áreas, com solos mais úmidos e menor quantidade de folhedo depositado na estação seca, em comparação com áreas de interflúvio. No entanto, essa formação também foi subdividida em três fitofisionomias (Fa1, Fa2 e Fa3 - Figura 4) devido a variações na altura (porte médio alto, médio a baixo e baixo) e densidade das árvores que compõem o dossel (densa ou esparsa). Essas variações fisionômicas podem estar relacionadas a distúrbios causados pelas cheias e vazantes 


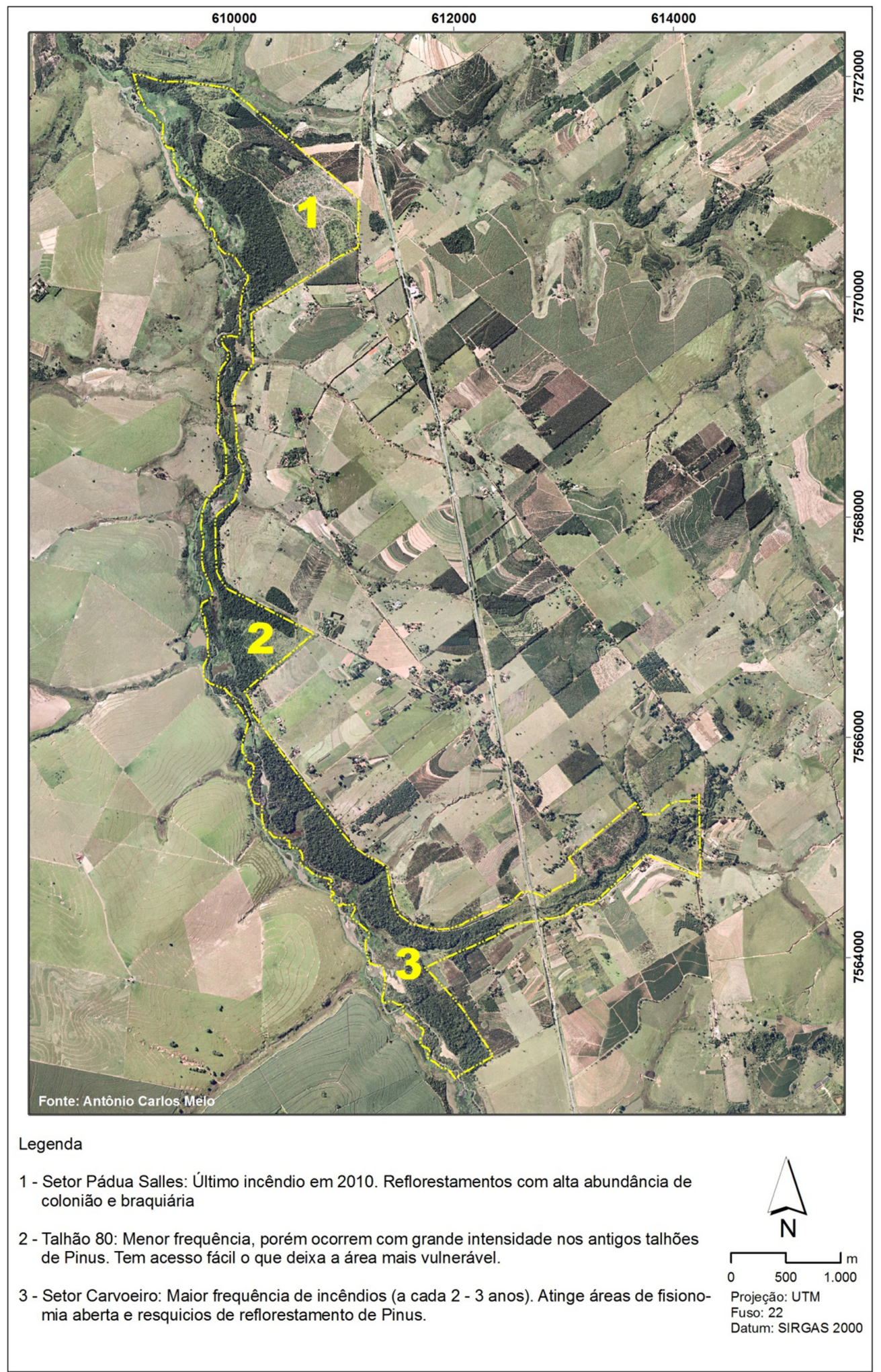

Figura 5. Áreas mais frequentemente afetadas por incêndios na Estação Ecológica de Marília, Marília-SP. Informações obtidas com o administrador da unidade.

Figure 5. Places where wildfires most commonly occur at the Marília Ecological Station, Marília-SP. The information was obtained from the conservation unit manager. 
IVANAUSKAS N. M.. et al. Diagnóstico e Propostas de Manejo da Vegetação da Estação Ecológica de Marília, SP, Sudeste do Brasil.

dos rios, além de processos de assoreamento observados e que podem influenciar a deposição de serapilheira, o estabelecimento de plântulas e, em consequência, a dinâmica desses ecossistemas.

Recebe a denominação de formação pioneira a vegetação que ocupa áreas de solo de deposição recente, ainda instáveis (Veloso, 1992). Enquadram-se nessa condição as planícies fluviais e depressões aluvionares (pântanos, lagunas e lagoas). Na Estação Ecológica de Marília, extensa área de formação pioneira foi mapeada ao longo do Rio Tibiriçá (100,49 ha ou $17 \%$ da área total, Tabela 2, Figura 4), sobre terrenos aluvionares oriundos de sedimentos provenientes de processos erosivos em suas nascentes, principalmente daquelas situadas em áreas agrícolas nos interflúvios de sua margem esquerda. Nos trechos de água empoçada e sujeitos aos efeitos das cheias do rio, instalou-se uma comunidade aluvial de hábito herbáceo a arbustivo, aqui subdividida entre aquela sujeita a inundação temporária ou permanente (Pah1, Figura 4) ou a presente em depressões e entorno de lagoas e sujeitas a inundação permanente (Pah2). Ambas são áreas assoreadas e cuja recuperação está vinculada à restauração das florestas nas áreas de preservação permanente de suas nascentes.

Como já relatado, esta vegetação herbáceo-arbustiva ocupava áreas distintas no mapeamento de 1973, no qual foi denominada de "Banhado", o que indica o caráter dinâmico dessas formações, muito sensíveis às variações de deposição e retirada de sedimentos causadas pelo Tibiriçá e seus afluentes, diretamente relacionadas à conservação do solo nos interflúvios.

Na classificação adotada pelo IBGE (2012), estão incluídas no sistema secundário as áreas onde houve intervenção humana para o uso da terra, seja com a finalidade mineradora, agrícola ou pecuária, portanto trechos florestais que foram sujeitos à corte raso. Na Estação Ecológica de Marília, áreas desse tipo encontramse atualmente propensas à regeneração natural da vegetação. $O$ tipo de distúrbio, a área atingida, a intensidade, a frequência e a época definem a extensão do dano e a resiliência do ecossistema, que pode variar de acordo com o banco de sementes local, a disponibilidade de propágulos, de dispersores e com as condições edáficas para o estabelecimento das plântulas (Magnago et al., 2015).

Nesse contexto, foram incluídas na legenda de Vegetação Secundária os trechos de Floresta Estacional Semidecidual Montana que foram sujeitos a corte raso para dar lugar aos reflorestamentos com espécies exóticas e que foram, posteriormente, abandonadas, permitindo ou não o avanço sucessional (Vs1 e Vs2 - Figura 4). Portanto, são áreas florestais de porte baixo e densas, que praticamente não existiam no mapeamento de 1973 (Figura 3), mas que atualmente podem ser consideradas como Capoeira (quarta fase da sucessão natural, Vs1 - Figura 4) e trechos aluviais atualmente ocupados por vegetação herbácea e que se encontram aparentemente estacionários na primeira fase de sucessão natural (Vs2 - Figura 4).

\subsection{Dados secundários sobre a vegetação da Estação Ecológica de Marília}

A produção científica sobre a vegetação nativa da área é resultante de uma tese de doutorado (Durigan, 1994) e das publicações correspondentes (a fitossociologia em Durigan e Leitão Filho, 1995, e a produção de folhedo e ciclagem de nutrientes em Durigan et al., 1996 e Durigan e Pagano, 2000). Os trabalhos referem-se ao levantamento florístico e fitossociológico realizado na Floresta Estacional Semidecidual Aluvial ao longo do Córrego Santa Helena (22 $01^{\prime}$ 'S e $49^{\circ} 55^{\prime}$ W), na então Estação Experimental de Marília, como parte de um estudo mais amplo sobre as matas ciliares da região oeste do Estado de São Paulo.

A amostragem da vegetação das espécies arbustivas e arbóreas foi realizada por meio de levantamento florístico e fitossociológico. Para o levantamento florístico foram feitas coletas mensais, com duração de um dia, durante cinco anos (1989-1993), em caminhamentos ao longo do córrego, concentrados nos $30 \mathrm{~m}$ a partir da margem (faixa mínima de preservação permanente). No levantamento fitossociológico foram incluídos indivíduos arbóreos com DAP $\geq 5,0 \mathrm{~cm}$, presentes no interior das 30 parcelas de $100 \mathrm{~m}^{2}(10 \mathrm{~m} \times 10 \mathrm{~m})$, distribuídas em três faixas de $10 \mathrm{~m}$ de largura a partir da margem do córrego Santa Helena.

Outros estudos científicos realizados na área referem-se a avaliações em plantios experimentais que foram implantados na Unidade com propósito de estudos sobre o comportamento silvicultural, 
conservação e melhoramento genético de espécies nativas com potencial econômico/madeireiro, com vistas à utilização sustentável.

Garrido et al. (1997) estudaram o desenvolvimento de Myracrodruon urundeuva Fr. All. (aroeira) em consorciação com Pinus caribaea Mor. var. caribaea Barr. \& Golf, em ensaios instalados na década de 1980, em duas situações: plantio simultâneo das duas espécies e plantio da aroeira em povoamento de Pinus com um ano de idade. Em ambos, foram empregados cinco tratamentos, com diferentes proporções das espécies utilizadas (aroeira correspondendo de $20 \%$ a $100 \%$ do total dos indivíduos). Entre três e sete anos após os plantios, foram realizadas avaliações de sobrevivência, medições dendrométricas e de forma de fuste. De maneira geral, os resultados demonstraram efeitos benéficos do sombreamento por Pinus no desenvolvimento da aroeira (em altura, forma de fuste e diâmetro), embasando recomendações dos autores para plantio dessa espécie nativa na proporção de 20 a 40\% dos indivíduos, em espaçamento 3 x 2m, após um ano do plantio de Pinus. Os autores sugeriram pesquisas complementares sobre épocas e desbastes da espécie exótica para obter um manejo ótimo para desenvolvimento da aroeira em altura e diâmetro, bem como boa forma de fuste.

Ettori et al. (1999) estudaram Cordia trichotoma (louro-pardo) em experimentos implantados nesta Unidade e na Estação Experimental de Luiz Antônio, com mudas produzidas a partir de sementes colhidas em populações naturais de Bauru (SP) e Tupi (SP). Os ensaios foram instalados em 1986 e as avaliações realizadas em diferentes idades, por meio de medidas de diâmetro à altura do peito (DAP - 1,30m a partir da base) e altura das plantas. Os dados foram utilizados na comparação de desenvolvimento entre as populações, por meio de estimativas de parâmetros quantitativos genéticos e não genéticos considerados de interesse para a seleção com objetivos de exploração para uso de madeira. Os resultados demonstraram, no geral, que a população de melhor desempenho foi a instalada em Luiz Antônio (crescimento em DAP, altura e sobrevivência), indicando que a região apresenta melhores condições edafoclimáticas para desenvolvimento de plantios de conservação ex situ da espécie.

Outros experimentos instalados na Unidade com propósitos semelhantes não tiveram dados adicionais de avaliações publicados até o momento e referem-se aos seguintes temas: número ideal de progênies para estimativa de parâmetros genéticos de aroeira, implantado em 1986 (área de 0,68 ha); teste de progênies de aroeira, procedência Bauru e Pederneiras, implantado em 1986 (área de 1,54 ha); desenvolvimento da aroeira consorciado com Pinus spp. ensaio I, implantado em 1988 (área de 9,80 ha) e desenvolvimento da aroeira consorciado com Pinus spp. ensaio II, implantado em 1986, área de 10,07 ha.

A partir de informações de projetos de pesquisa cadastrados na Comissão Técnico-Científica do Instituto Florestal (COTEC - IF) para execução na Estação Ecológica de Marília, foram localizados dois estudos de taxonomia, sendo uma dissertação de mestrado sobre a família Mayacaceae (Carvalho, 2007) e uma tese de doutorado (Bordin, 2011) sobre a família Fissidentaceae (Bryophyta), que, no entanto, não mencionam a Unidade nos métodos/locais de coleta, nem apresentam dados específicos sobre a área.

\subsection{Flora da Estação Ecológica de Marília}

A flora proveniente de dados secundários totalizou 123 espécies, das quais 67 provenientes dos inventários florísticos e fitossociológicos (Durigan, 1994 e Durigan e Leitão Filho, 1995), 80 de coleções científicas (INCT, 2014) e 33 espécies comuns a essas duas fontes. Outras nove espécies foram acrescidas à listagem pois constam nos talhões de exóticas registradas no mapeamento de 1973 (Figura 3) e que ainda apresentam indivíduos remanescentes na Estação.

No levantamento de dados primários foram registradas 254 espécies de plantas, das quais 75 já constavam na lista de dados secundários ( 27 comuns aos inventários florísticos e fitossociológicos, 20 comuns às coleções científicas e 28 comuns a essas duas fontes). Portanto, durante os estudos para o Plano de Manejo, foram acrescidas 179 novas citações de espécies para a Estação Ecológica de Marília. 
IVANAUSKAS N. M.. et al. Diagnóstico e Propostas de Manejo da Vegetação da Estação Ecológica de Marília, SP, Sudeste do Brasil.

A compilação de dados primários e secundários totalizou 302 espécies, das quais 25 exóticas (Tabela 3). Dentre estas, estão listadas nove espécies de pinheiros e eucaliptos cultivadas, mas que não foram observadas invadindo áreas naturais. Importante destacar que Pinus elliottii, que é comprovadamente uma espécie invasora de áreas savânicas (Abreu e Durigan, 2011), até o momento não representa um problema para as áreas de floresta nativa na Estação Ecológica de Marília.

Considerando somente as espécies exóticas registradas em áreas naturais, foram registradas 16 espécies, distribuídas em três diferentes situações: presentes, estabelecidas e invasoras de áreas naturais (Zalba, 2005).

$\mathrm{Na}$ categoria de exótica presente em áreas naturais foram registradas as árvores ornamentais Libidibia ferrea e Tipuana tipu, pois indivíduos isolados destas espécies estavam situados na borda de florestas nativas ou em áreas ruderais, aparentemente não mantendo descendentes no local. Também as palmeiras Livistonia chinensis e Phoenix canariensis e a árvore Cordia myxa foram cultivadas no interior da Estação, encontradas já em fase reprodutiva em áreas vizinhas a fragmentos de floresta nativa. Como seus frutos são muito apreciados e dispersos pela fauna, é bastante provável que indivíduos provenientes dessas matrizes já tenham se estabelecido nos fragmentos de floresta nativa. Portanto, essas espécies representam um potencial de invasão futuro, e não uma situação atual de problema. Nesse contexto, recomenda-se o corte imediato das matrizes e o monitoramento das áreas de entorno, frente ao potencial que estas espécies apresentam para se tornarem invasoras de áreas naturais.

Outras seis espécies exóticas foram consideradas estabelecidas em áreas naturais, pois foram encontrados indivíduos isolados já no interior de florestas nativas, em fase reprodutiva. Nesta categoria encontram-se as frutíferas Citrus latifolia e Mangifera indica, a forrageira Leucaena leucocephala e a ornamental Melia azederach. Também figura nesta categoria Schizolobium parahyba, nativa da Floresta Ombrófila Densa do litoral brasileiro, portanto exótica para a Floresta Estacional Semidecidual do interior paulista. Todas as espécies citadas foram introduzidas na área por meio de cultivo inadequado, seja para fins ornamentais ou para consumo de frutos. Embora ainda não possam ser consideradas como invasoras agressivas na Estação Ecológica, o manejo visando à erradicação dessas espécies dentro da unidade é recomendado (Durigan et al., 2013).

Cinco espécies foram classificadas como exóticas invasoras, ou seja, indivíduos dessas espécies se estabeleceram em áreas naturais e obtiveram sucesso nos processos de reprodução e dispersão, a ponto de conseguirem se expandir a partir do ponto inicial em que foram introduzidas. Psidium guajava foi a única arbórea incluída nesta categoria, observada em fase reprodutiva em diferentes pontos no interior de trechos florestais degradados por ação antrópica. Oeceoclades maculata é uma orquídea terrestre exótica e que se encontra em franca expansão no sub-bosque de florestas do interior paulista. Já as gramíneas africanas Megathyrsus maximus, Cenchrus purpureus e Urochloa decumbens são comumente associadas às perturbações freqüentes na borda dos fragmentos, causando impactos negativos por aumentar o risco de incêndios e dificultar o estabelecimento de espécies nativas, afetando a germinação de sementes a partir do banco ou provenientes de chuva de sementes. A erradicação de exóticas invasoras, apesar de desejável, é extremamente difícil e requer ações de controle e manejo de longo prazo.

Excluindo-se as exóticas, foram registradas na Estação Ecológica de Marília 277 espécies nativas, pertencentes a 185 gêneros e 73 famílias (Tabela 4). Cada fonte de compilação de dados contribuiu com registros exclusivos, portanto a busca por espécies em publicações e coleções científicas foi importante, mas as expedições a campo realizadas para o Plano de Manejo se revelaram indispensáveis para o aumento do conhecimento da flora da Estação Ecológica.

No entanto, pode-se afirmar que esta flora ainda está subamostrada. Esta conclusão baseia-se na distribuição da riqueza de espécies de acordo com o hábito (Figura 6). Houve maior esforço de coleta 
IVANAUSKAS N. M.. et al. Diagnóstico e Propostas de Manejo da Vegetação da Estação Ecológica de Marília, SP, Sudeste do Brasil.

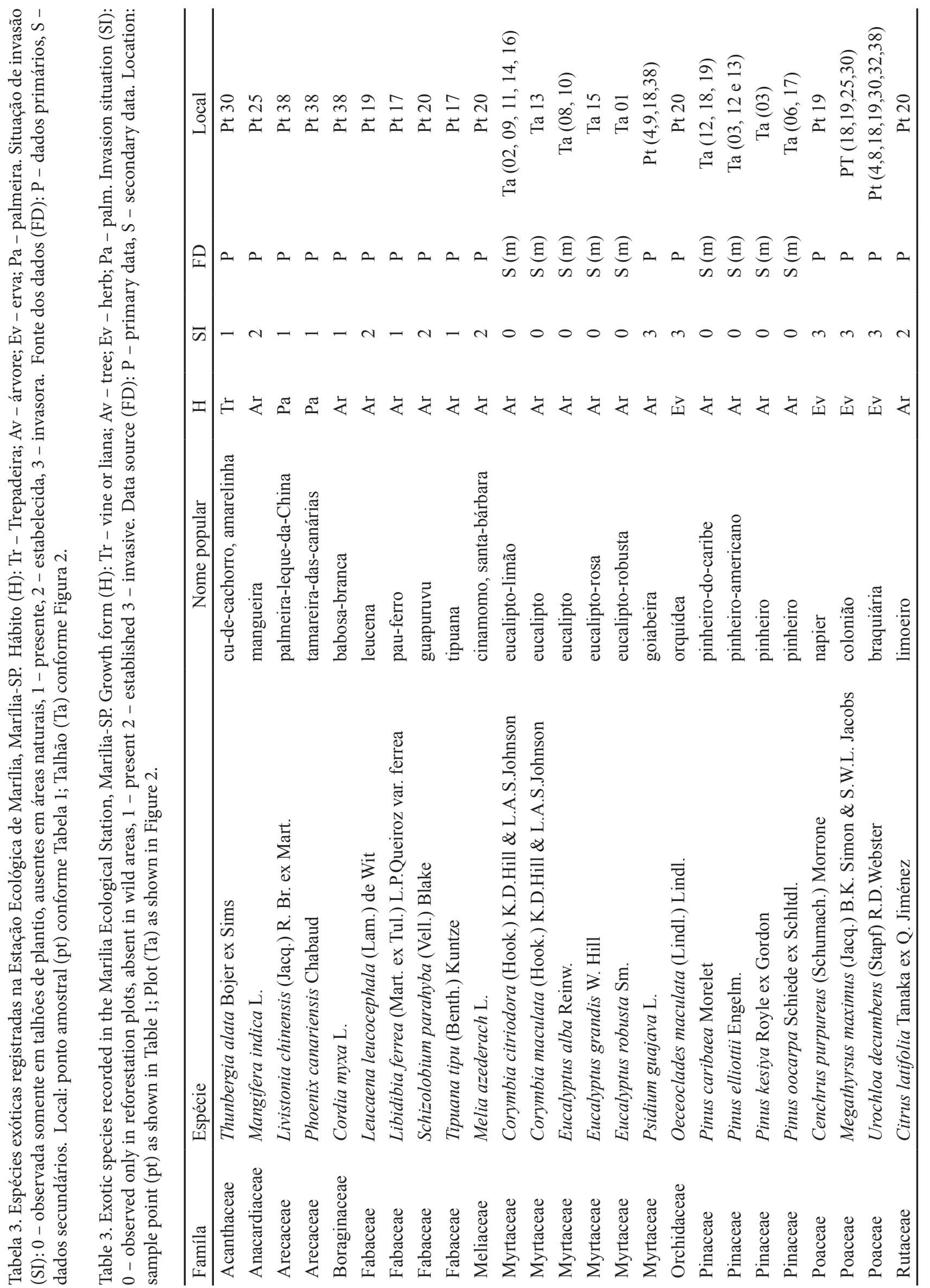


IVANAUSKAS N. M.. et al. Diagnóstico e Propostas de Manejo da Vegetação da Estação Ecológica de Marília, SP, Sudeste do Brasil.

dirigido àquelas de hábito arbóreo (62\%), em detrimento de outras formas de crescimento, as quais geralmente representam cerca de $50 \%$ da riqueza de espécies em florestas tropicais (Ivanauskas et al., 2001). O fato da equipe contar com uma especialista em trepadeiras também contribuiu para o grande esforço de coleta dessa forma de vida ( $26 \%$ das espécies), mas ainda há necessidade de estudos dirigidos para a coleta de ervas terrestres e epífitas.

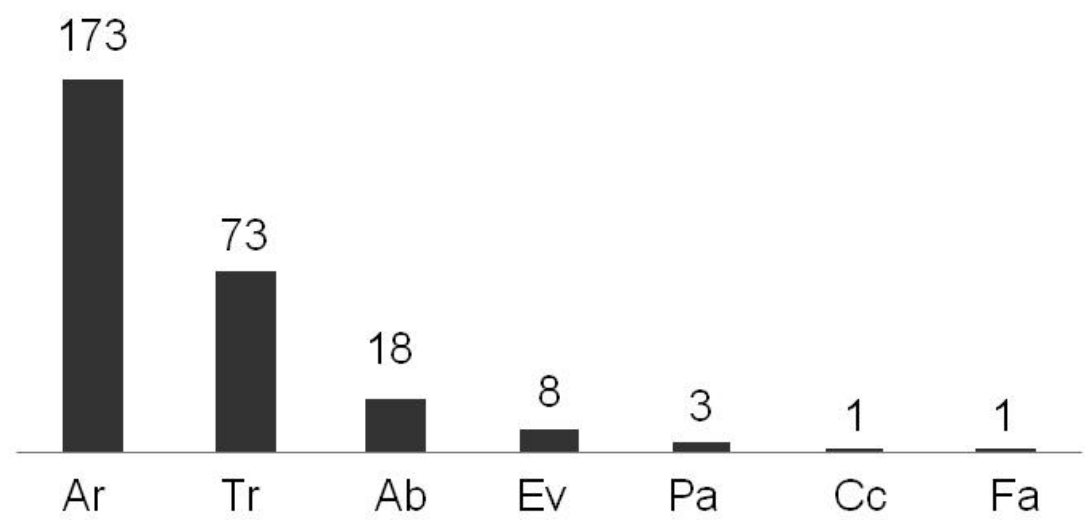

Figura 6. Riqueza de espécies nativas na Estação Ecológica de Marília, agrupadas por hábito. Ar - árvore, Tr - trepadeira, $\mathrm{Ab}$ - arbusto, Ev - erva, $\mathrm{Pa}$ - palmeira, $\mathrm{Cc}$ - cactos, $\mathrm{Fa}$ - feto arborescente.

Figure 6. Native species richness in the Marilia Ecological Station, pooled by growth form. Ar - tree, $\operatorname{Tr}-\mathrm{vine}, \mathrm{Ab}-\mathrm{shrub}$, $\mathrm{Ev}$ - herb, Pa - palm tree, Cc - cacti, Fa - tree fern.

As famílias mais ricas em espécies foram Fabaceae (40 espécies), Bignoniaceae (30) e Myrtaceae (18), novamente refletindo o maior esforço de coleta entre espécies de hábito arbóreo (Fabaceae e Myrtaceae) e trepadeiras (Bignoniaceae).

Entre as espécies nativas listadas, oito estão presentes em uma ou mais listas de espécies ameaçadas de extinção (Tabela 5), nas categorias em perigo ou vulnerável. Seis espécies apresentam hábito arbóreo e duas são trepadeiras. Com exceção de Apuleia leiocarpa, indivíduos de todas essas espécies foram observados em campo na coleta de dados primários, indício de que populações ameaçadas ainda se mantêm localmente.

O registro de duas trepadeiras entre aquelas ameaçadas de extinção é um alerta para o cuidado que se deve empregar no manejo de fragmentos. Estudos de dinâmica florestal têm sido realizados a fim de verificar se os remanescentes de Floresta Estacional Semidecidual do interior paulista apresentam resiliência suficiente para recuperar sua estrutura e funcionalidade, frente aos distúrbios históricos a que foram sujeitos durante décadas de exploração e degradação. As dúvidas recaem principalmente sobre o potencial de auto-regeneração dos pequenos fragmentos, onde a manutenção de um dossel arbóreo contínuo parece ser fundamental para a manutenção dos processos ecológicos. 
IVANAUSKAS N. M.. et al. Diagnóstico e Propostas de Manejo da Vegetação da Estação Ecológica de Marília, SP, Sudeste do Brasil.

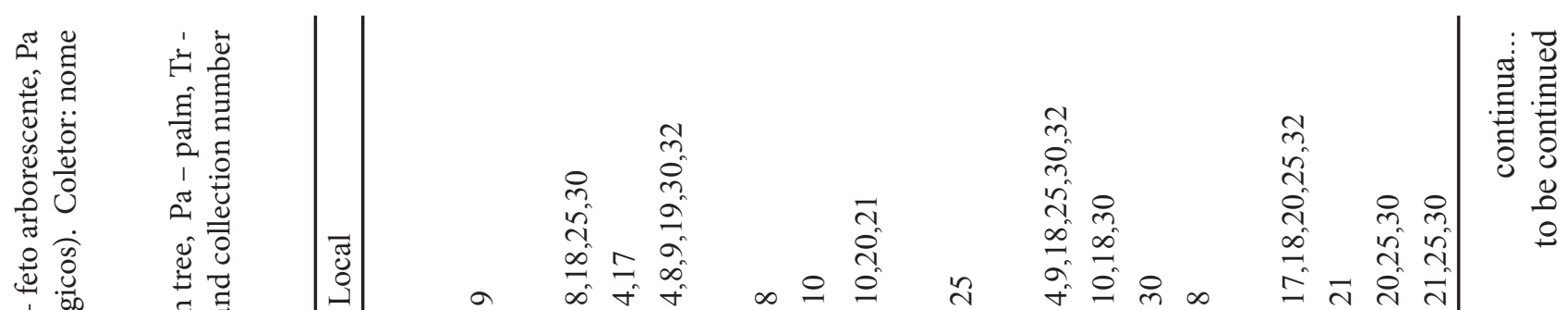

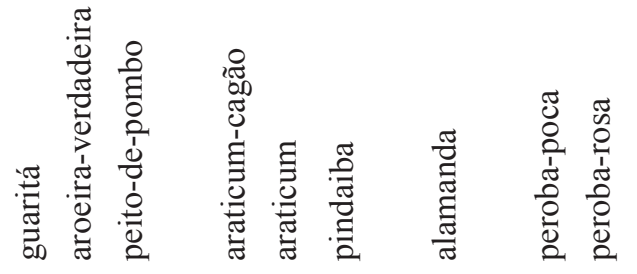


IVANAUSKAS N. M.. et al. Diagnóstico e Propostas de Manejo da Vegetação da Estação Ecológica de Marília, SP, Sudeste do Brasil.

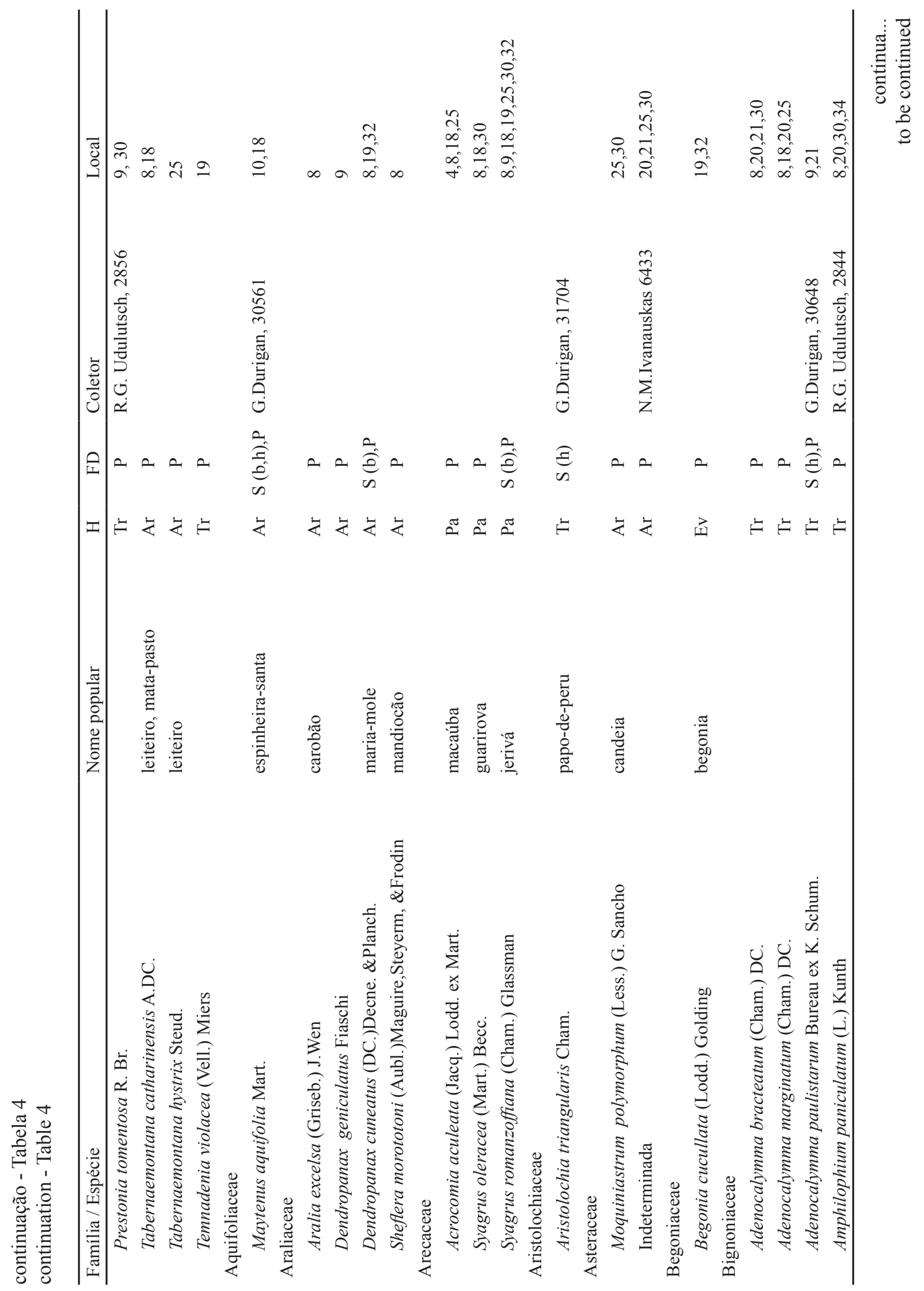


IVANAUSKAS N. M.. et al. Diagnóstico e Propostas de Manejo da Vegetação da Estação Ecológica de Marília, SP, Sudeste do Brasil.

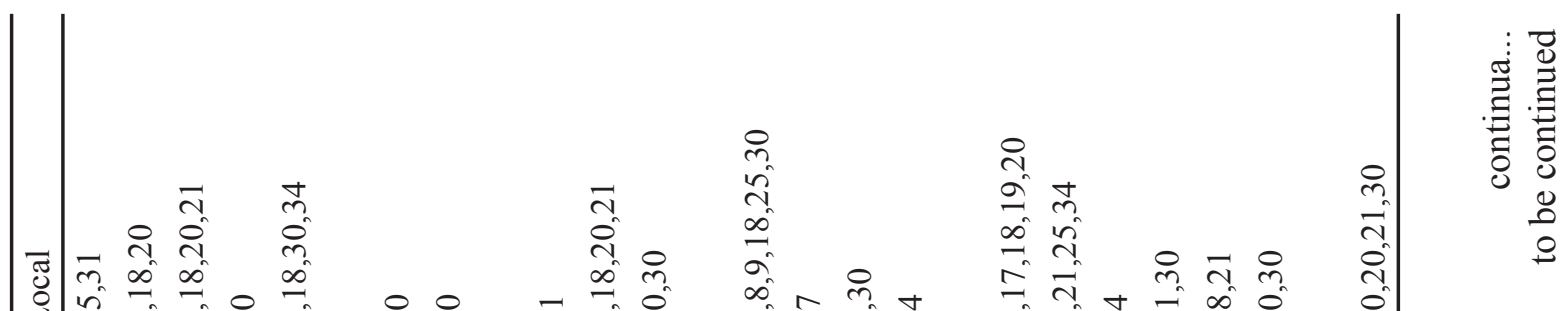

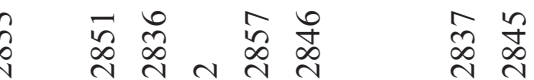

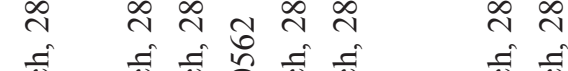

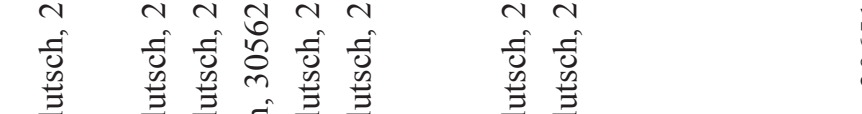

当

䏤䏤兽䏤

䏤总

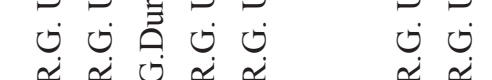

芒

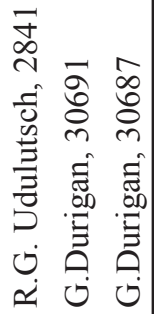

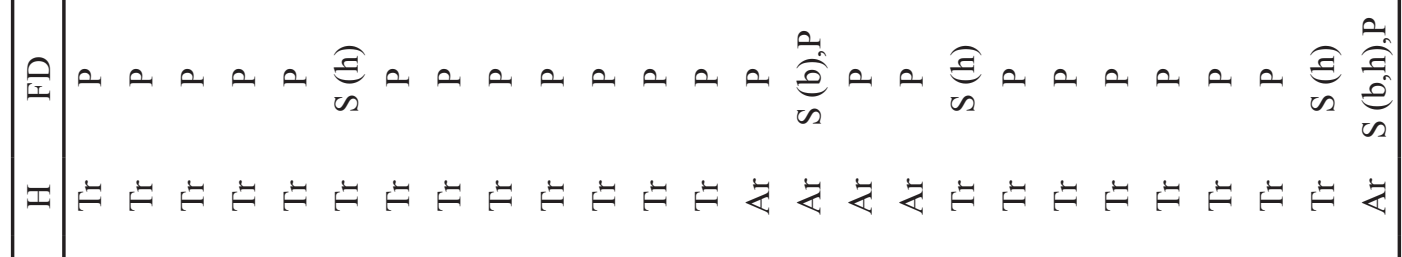

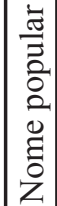

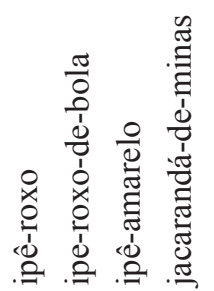

0
10
0
1
100
0
1
0
0
1
0
$\frac{0}{0}$
0

刍

\section{ت્屯 \\ 章} $\exists$ थ $\ddot{D}$

$\ddot{v}$

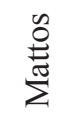

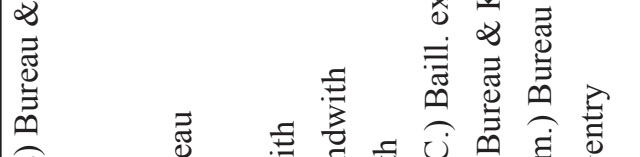

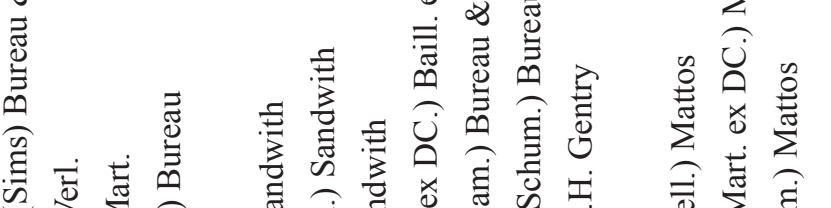

竞总

苟

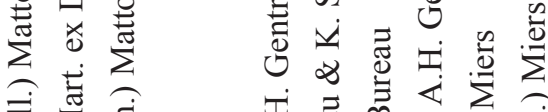
I 
IVANAUSKAS N. M.. et al. Diagnóstico e Propostas de Manejo da Vegetação da Estação Ecológica de Marília, SP, Sudeste do Brasil.

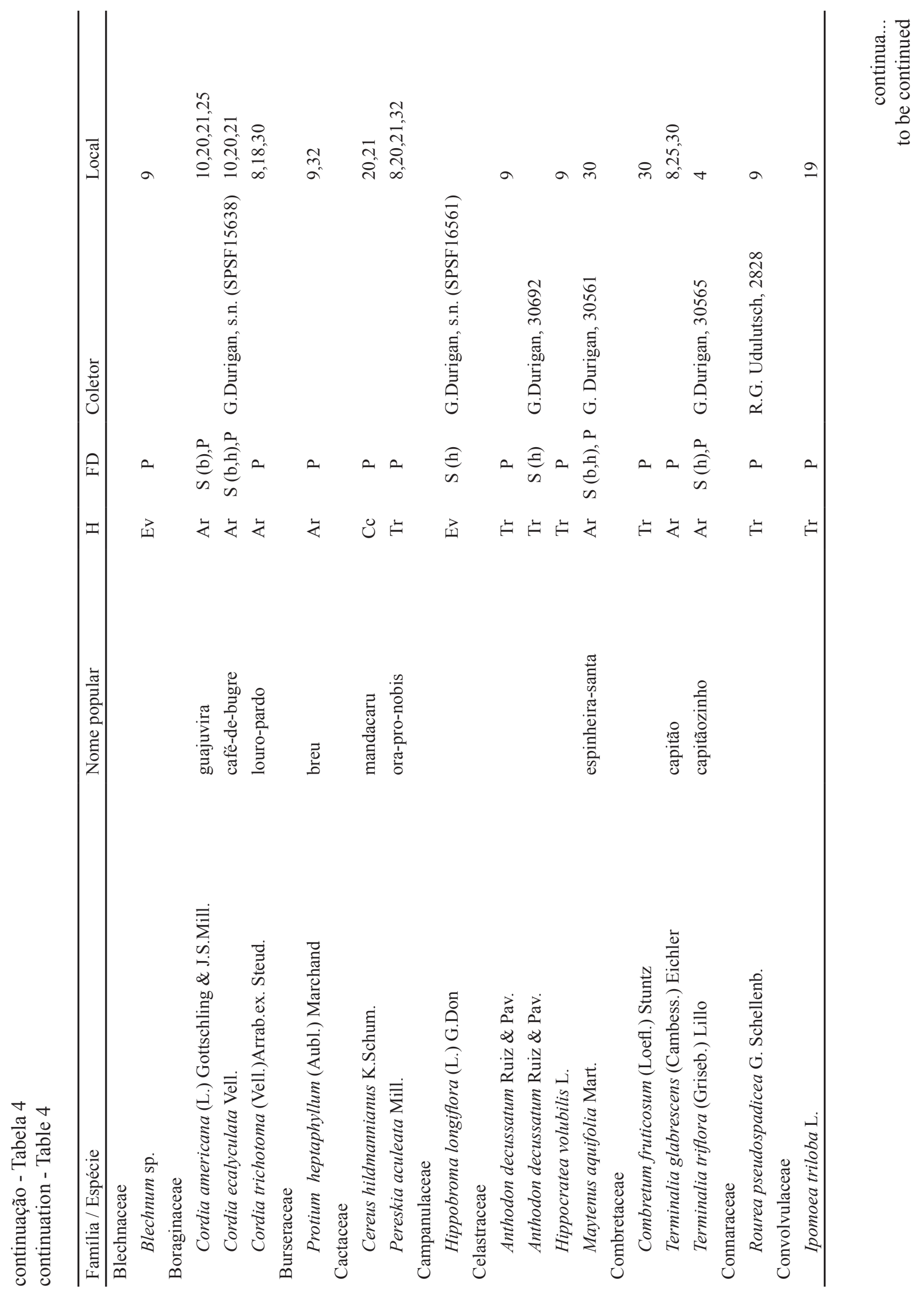




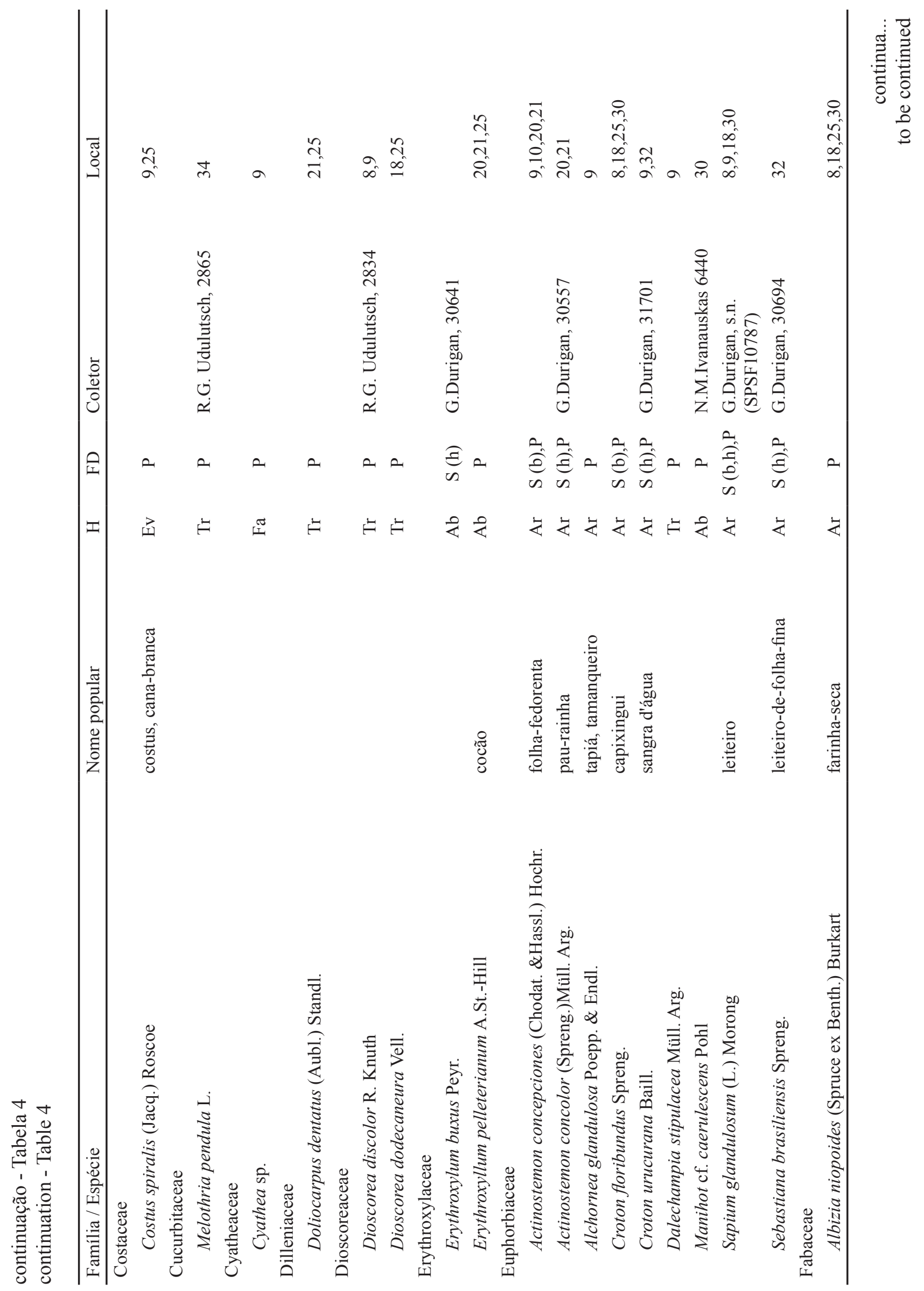


IVANAUSKAS N. M.. et al. Diagnóstico e Propostas de Manejo da Vegetação da Estação Ecológica de Marília, SP, Sudeste do Brasil.

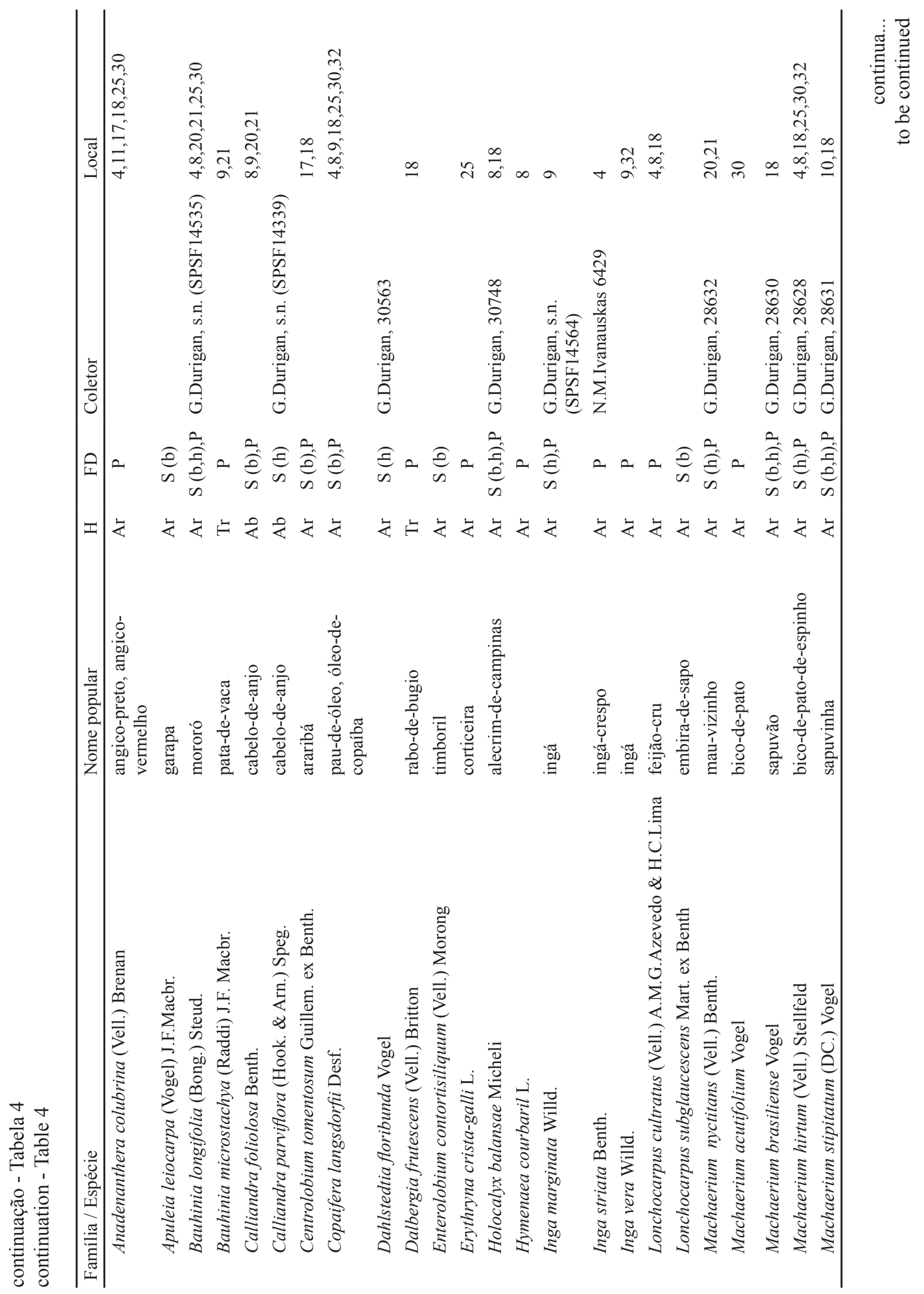




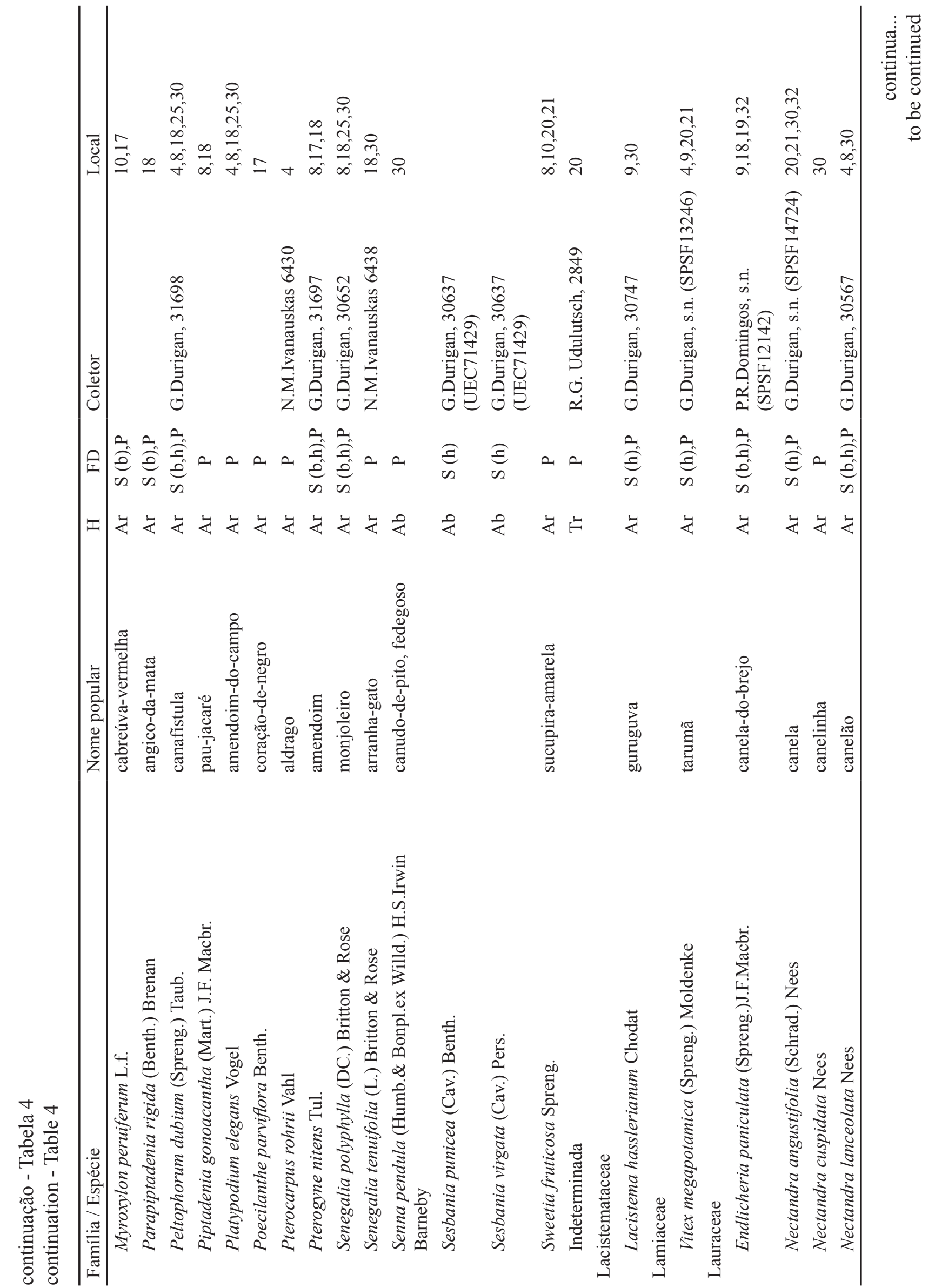


IVANAUSKAS N. M.. et al. Diagnóstico e Propostas de Manejo da Vegetação da Estação Ecológica de Marília, SP, Sudeste do Brasil.

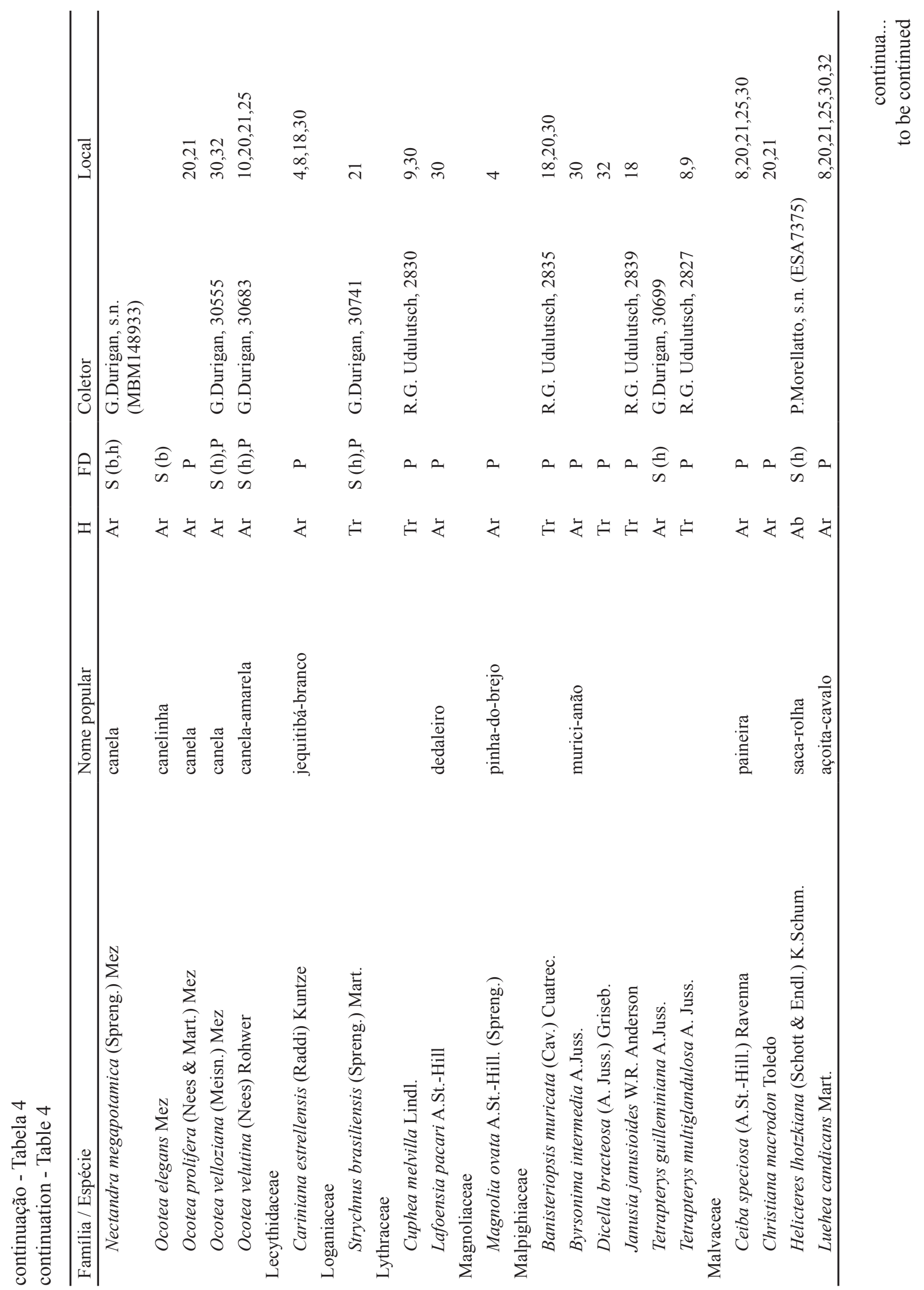




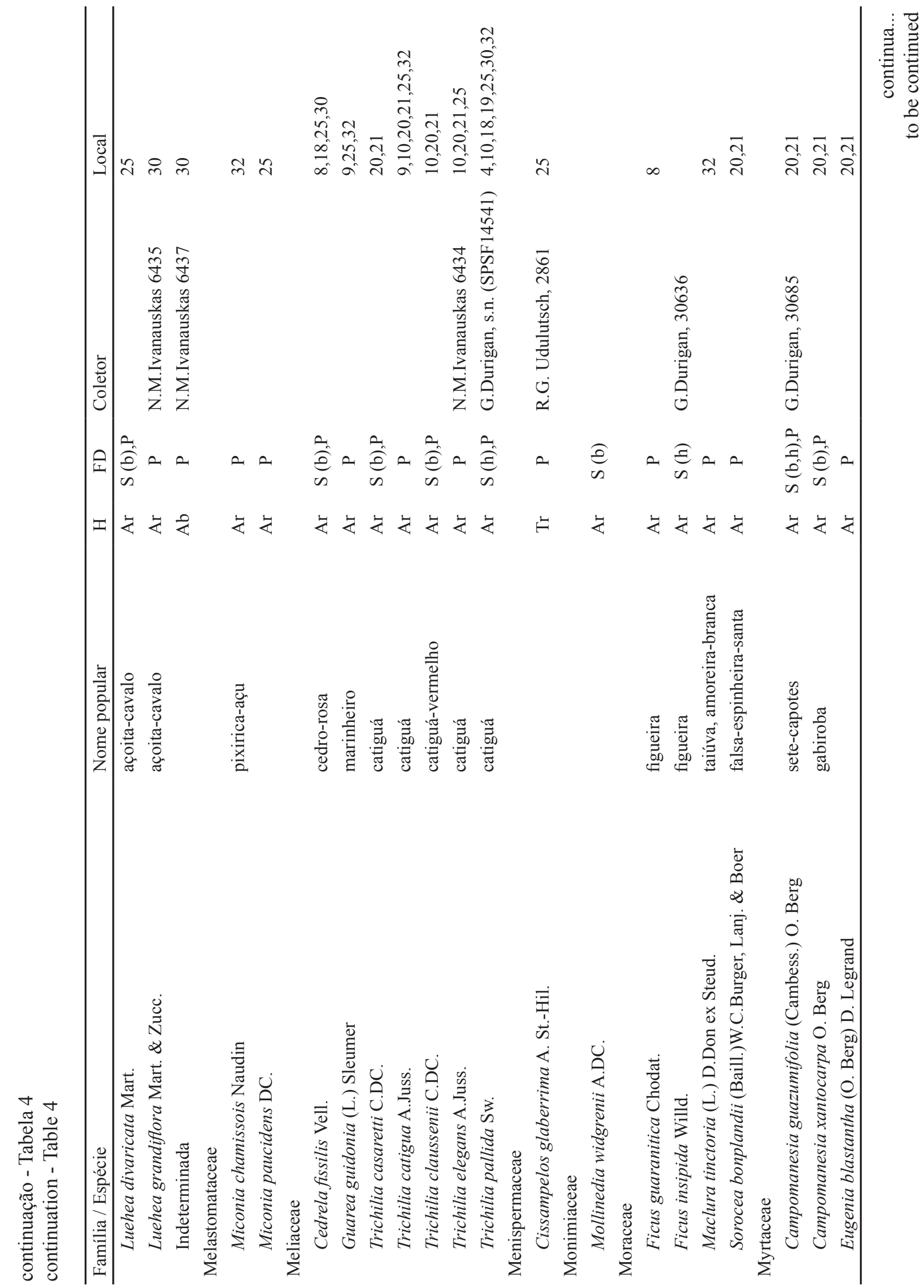


IVANAUSKAS N. M.. et al. Diagnóstico e Propostas de Manejo da Vegetação da Estação Ecológica de Marília, SP, Sudeste do Brasil.

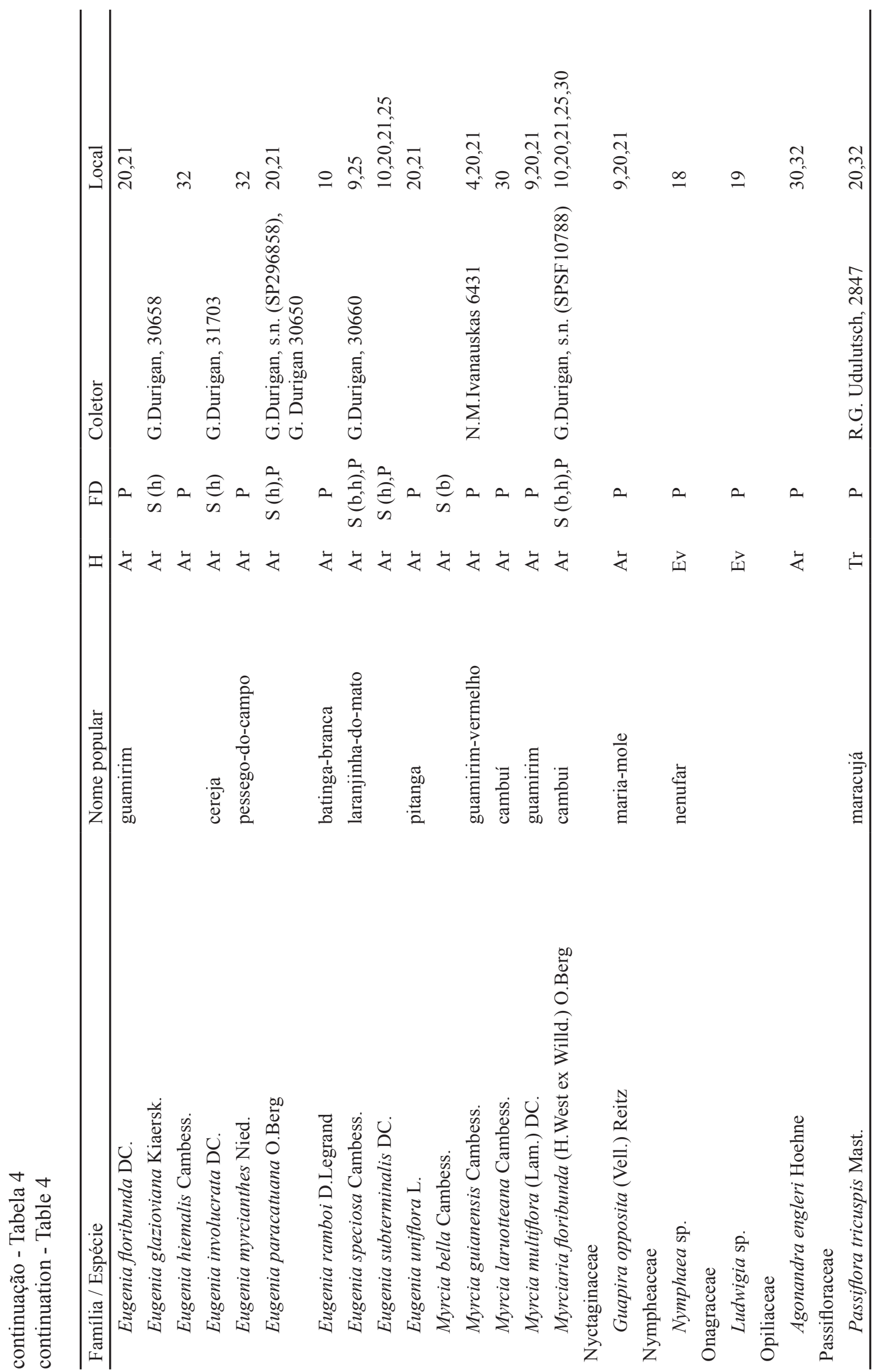

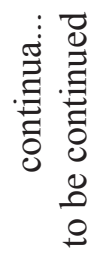




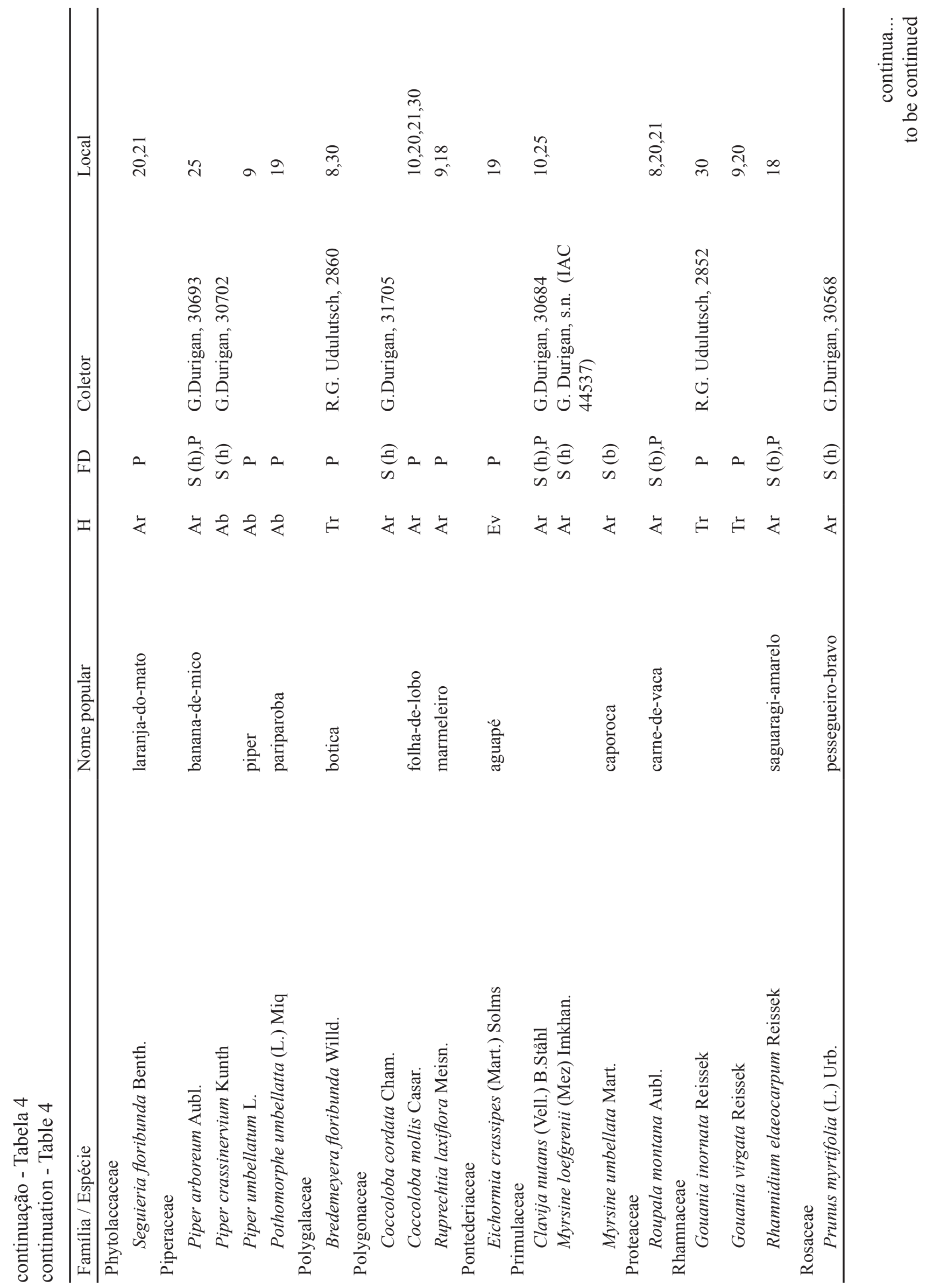


IVANAUSKAS N. M.. et al. Diagnóstico e Propostas de Manejo da Vegetação da Estação Ecológica de Marília, SP, Sudeste do Brasil.

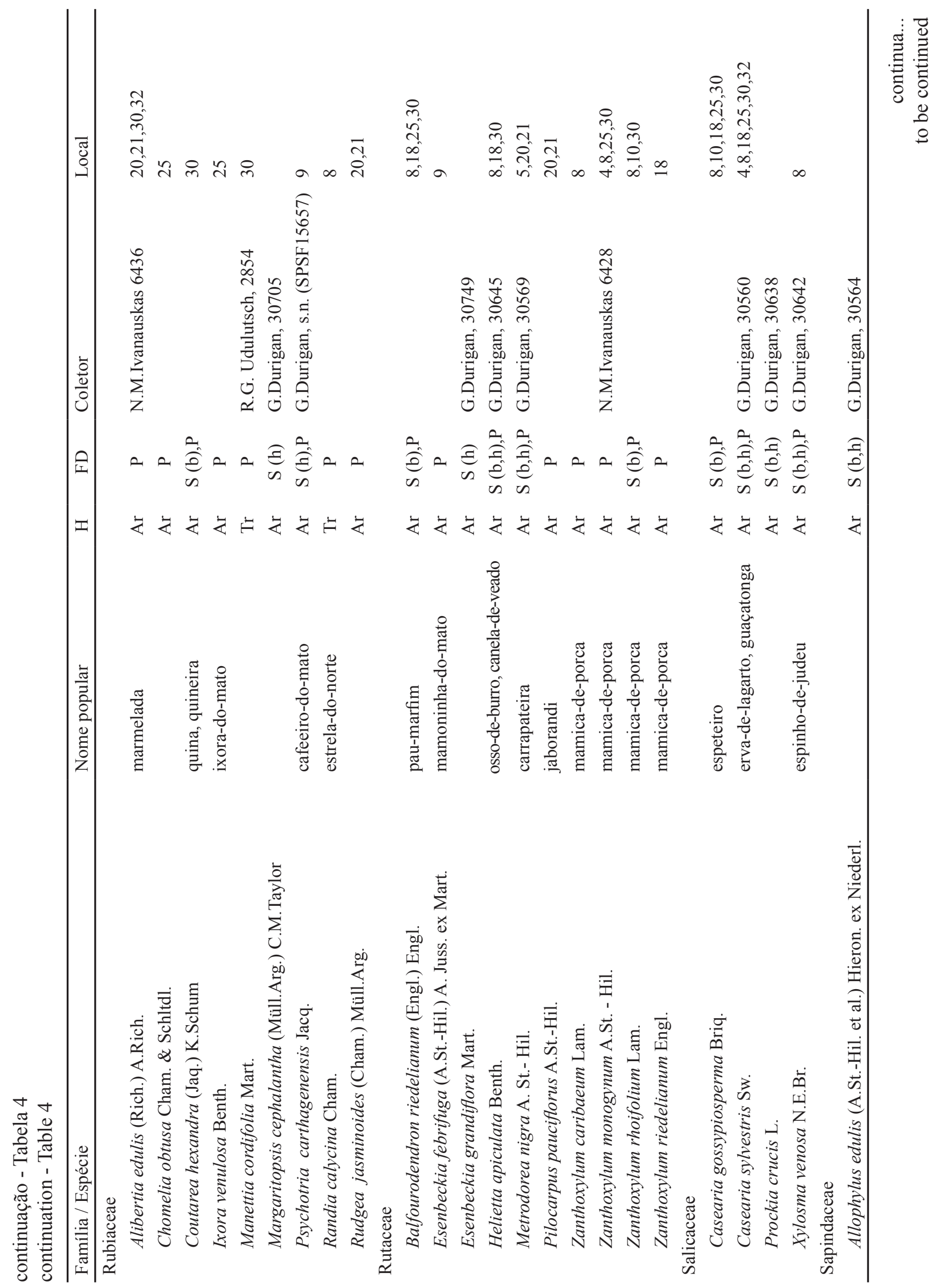




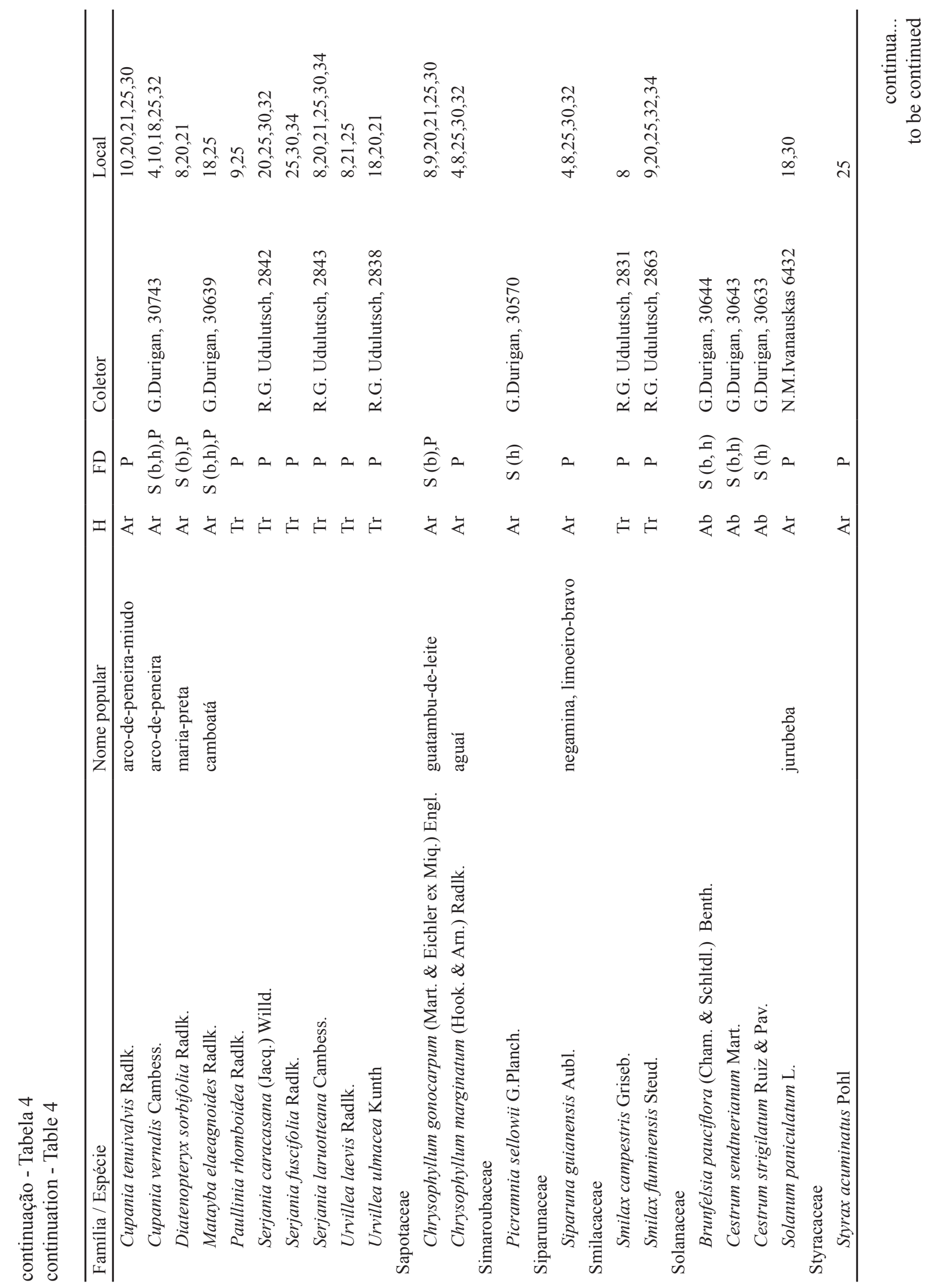


IVANAUSKAS N. M.. et al. Diagnóstico e Propostas de Manejo da Vegetação da Estação Ecológica de Marília, SP, Sudeste do Brasil.

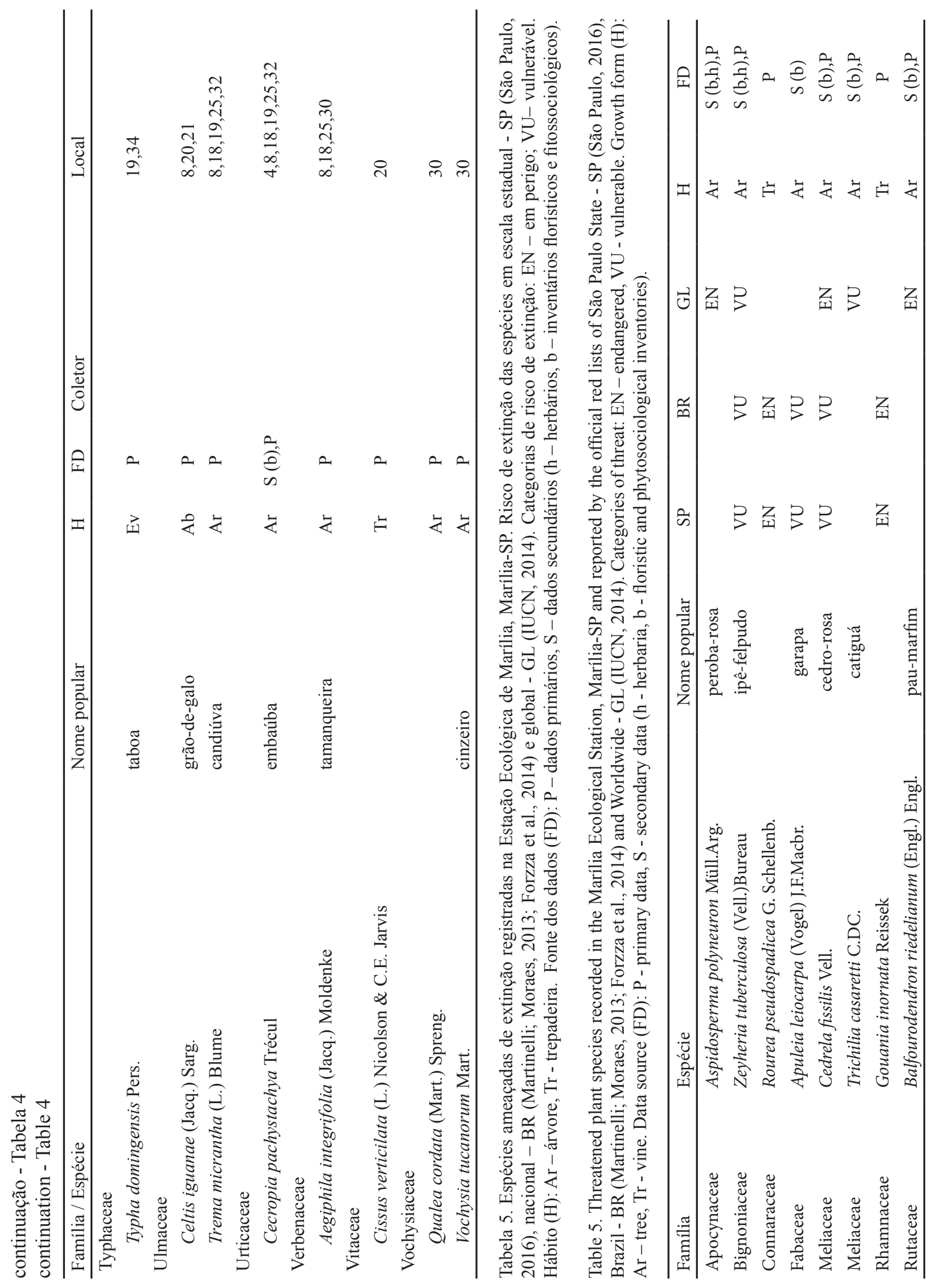


IVANAUSKAS N. M.. et al. Diagnóstico e Propostas de Manejo da Vegetação da Estação Ecológica de Marília, SP, Sudeste do Brasil.

Farah et al. (2014) citam a morte de indivíduos adultos do dossel como um importante indicador de degradação, com o estabelecimento de cobertura florestal menos densa de pequenas árvores, susceptíveis de serem recobertas por trepadeiras, as quais podem limitar o crescimento dessas juvenis e comprometer a estrutura florestal. Nesse contexto, técnicas de manejo adaptativo, entre essas o corte controlado de trepadeiras, são recomendadas como meio de reverter o processo de desestruturação florestal e acelerar os processos de sucessão natural.

Na Estação Ecológica de Marília foram registradas 73 espécies de trepadeiras nativas, as quais são fontes de recursos essenciais para a manutenção da fauna local, pois muitas disponibilizam flores e frutos em períodos de baixa oferta pelos arbustos e árvores (Engel et al., 1997; Morellato, 2003). No entanto, oito espécies de trepadeiras, localizadas principalmente nas bordas dos fragmentos, podem formar populações com biomassa além do desejável, tornando-se espécies-problema. Nesse caso, a ação de manejo necessária é temporária, pois visa apenas restabelecer o estado normal dessas populações nativas.

Nesse contexto, recomendam-se projetos específicos para o estudo da auto-ecologia e manejo das espécies de trepadeiras que apresentam potencial para se tornarem espécies-problema: cinco espécies de Bignoniaceae (Adenocalymma marginatum, Amphilophium paniculatum, Arrabidaea florida, Cuspidaria convoluta e Macfadyena unguis-cati) e três espécies de Sapindaceae (Serjania caracasana, Serjania laruotteana e Urvillea laevis).

\subsection{Zoneamento da Estação Ecológica de Marília}

\subsubsection{Lacunas de conhecimento e áreas prioritárias para a pesquisa da flora}

O grau de conhecimento botânico da Estação Ecológica de Marília possui estreita relação com os estudos botânicos pré-existentes (Figura 7). Nota-se que somente as áreas mais conservadas de Floresta Estacional Semidecidual já foram objeto de estudo. Nada se sabe sobre as formações pioneiras e as áreas de vegetação secundária, que sofreram corte raso e se encontram em processo de sucessão natural. Também não há informações disponíveis sobre a presença/ausência de sub-bosque de nativas sob os reflorestamentos com espécies exóticas, informação que deverá ser considerada no manejo dessas áreas.

As áreas prioritárias para pesquisa da flora (Figura 8) estão inversamente relacionadas às áreas de menor conhecimento botânico e devem nortear as próximas ações de pesquisa, a fim de uniformizar o grau de conhecimento entre as formações vegetais naturais nos diferentes estádios sucessionais. Foi dada maior prioridade de pesquisa para as áreas nativas bem conservadas, pois são as de maior riqueza e que apresentam maior probabilidade de abrigar populações de espécies ameaçadas. Esses fragmentos também são considerados áreas-fonte para o enriquecimento das áreas degradadas no entorno. Além das florestas maduras, assume importância o inventário florístico das formações pioneiras, já que a comunidade arbustivo-herbácea ali presente não foi suficientemente amostrada e pode apresentar particularidades regionais, aliada à necessidade de monitoramento em relação às espécies exóticas invasoras.

As formações secundárias foram consideradas de média prioridade para inventários florísticos, já que usualmente predominam populações de espécies iniciais da sucessão (pioneiras ou secundárias iniciais). No entanto, a caracterização em maior detalhe pode ser útil para projetos de manejo visando ao enriquecimento desses locais, como meio de expandir o tamanho das populações ameaçadas presentes nas áreas mais conservadas da Estação Ecológica. Não menos importante é o uso das espécies iniciais de sucessão comuns nessas áreas e que possam auxiliar no rápido recobrimento em projetos de restauração do entorno, com ênfase naquelas mais atrativas para a fauna e as que possam sombrear as gramíneas exóticas, a fim de desencadear a formação de núcleos de regeneração sob suas copas. 
IVANAUSKAS N. M.. et al. Diagnóstico e Propostas de Manejo da Vegetação da Estação Ecológica de Marília, SP, Sudeste do Brasil.

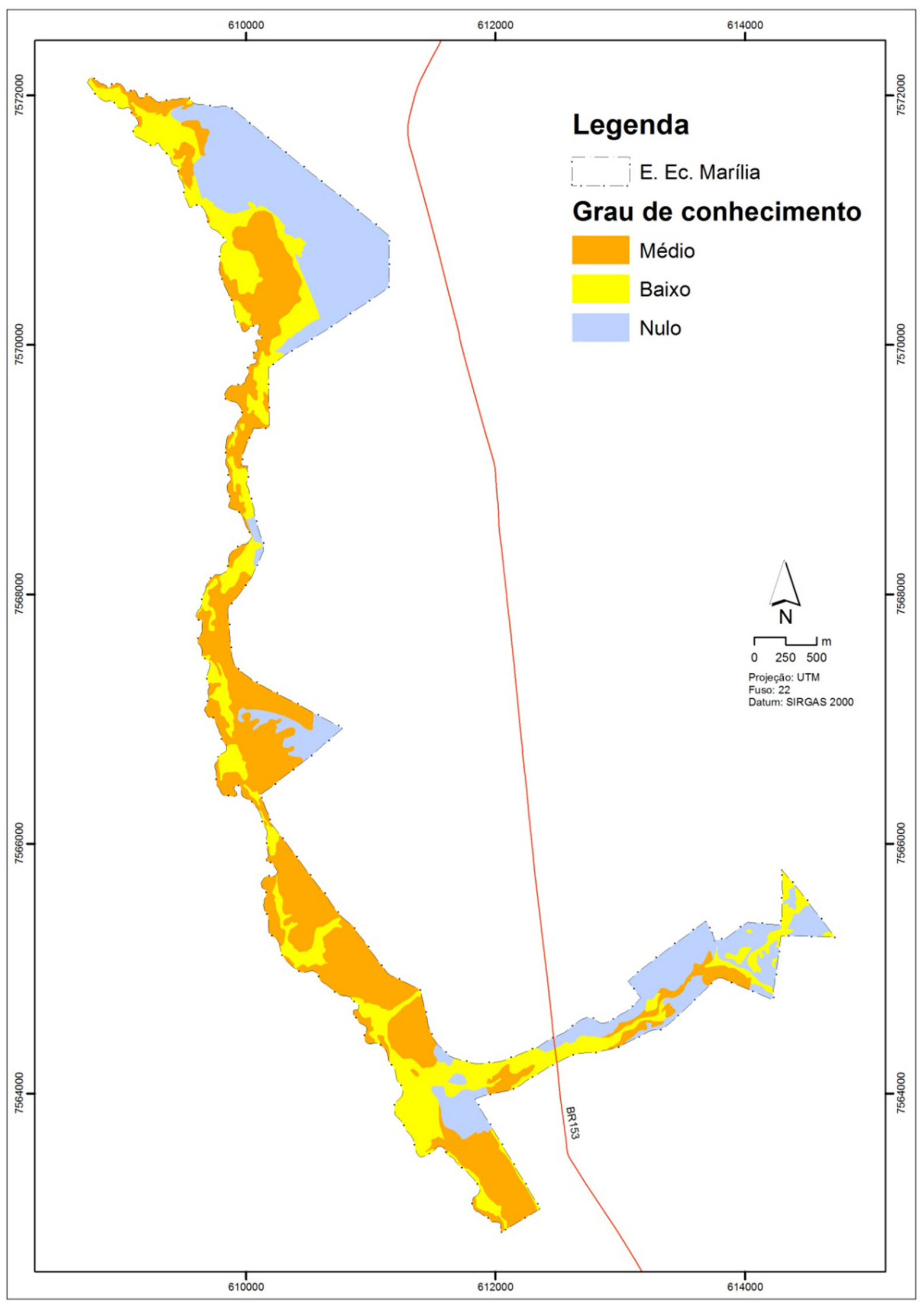

Figura 7. Grau de conhecimento da flora na Estação Ecológica de Marília, Marília-SP.

Figure 7. Degree of botanical knowledge in the Marília Ecological Station, Marília-SP. 
IVANAUSKAS N. M.. et al. Diagnóstico e Propostas de Manejo da Vegetação da Estação Ecológica de Marília, SP, Sudeste do Brasil.

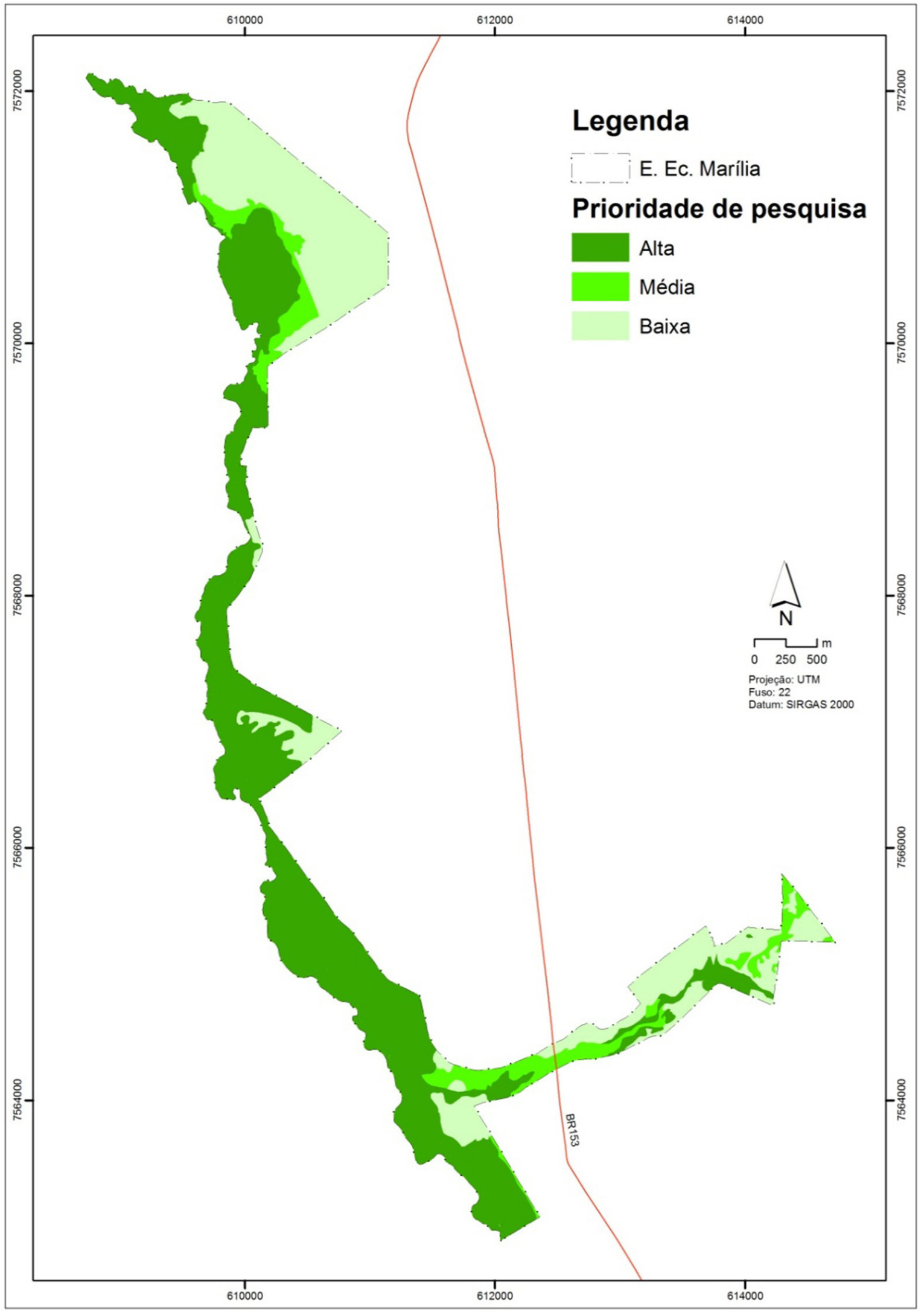

Figura 8. Locais prioritários para pesquisa da flora na Estação Ecológica de Marília, Marília-SP.

Figure 8. Priority areas for botanical science research in the Marília Ecological Station, Marília-SP. 
IVANAUSKAS N. M.. et al. Diagnóstico e Propostas de Manejo da Vegetação da Estação Ecológica de Marília, SP, Sudeste do Brasil.

Por fim, as áreas atualmente ocupadas com reflorestamentos de espécies exóticas ou muito antropizadas foram consideradas de baixa prioridade para pesquisa da flora. A necessidade de estudos sobre a vegetação local é maior do ponto de vista de processos sucessionais e ecologia de comunidades (resiliência, competição, dinâmica de comunidades), para que possam dar suporte às decisões sobre o potencial de regeneração natural, à necessidade de manejo adaptativo ou de plantios de restauração. Com relação às pesquisas em vegetação, devem ser priorizados os experimentos sobre restauração florestal. Estudos complementares de flora podem subsidiar a escolha das espécies a serem usadas nos projetos de revegetação com espécies nativas.

\subsection{2 Áreas prioritárias para a conservação}

A categorização ambiental dos trechos amostrados na Avaliação Ecológica Rápida para o tema vegetação, de acordo com o grau de importância, é apresentada na Figura 9.

Foram considerados de importância extrema para a conservação os trechos de Floresta Estacional Semidecidual Montana e Aluvial em bom estado de conservação (Fm1, Fa1, Fa2 e Fa3 na Figura 3), onde as ações de manejo incluem apenas o isolamento de possíveis vetores de degradação, já que possuem estrutura e riqueza em espécies características de floresta madura.

Os trechos de Floresta Estacional com sinais de degradação (Fm2, Fm3) foram considerados de alta prioridade para a conservação, pois apesar de abrigarem elevada riqueza de espécies nativas, predominam nesses trechos populações de algumas espécies de trepadeiras que produzem bastante biomassa, as formações pioneiras ( $\mathrm{Pa} 1$ e $\mathrm{Pa} 2)$ e as áreas de vegetação secundária.

As áreas antropizadas e com reflorestamentos usando espécies nativas e exóticas foram consideradas, comparada às demais, como de baixa prioridade para conservação.

\subsubsection{Proposta de zoneamento embasada na vegetação}

\subsubsection{Zona Primitiva $(248,55$ ha ou $40,98 \%$ da área)}

Locais onde os ecossistemas característicos da UC encontram-se preservados, tendo ocorrido pequena ou mínima intervenção humana. Os ecossistemas podem abrigar espécies endêmicas, raras ou ameaçadas de extinção. O objetivo geral é a preservação do ambiente natural e, ao mesmo tempo, a realização de atividades de pesquisa e educação ambiental. Portanto, são permitidas atividades de pesquisa científica de médio e baixo impacto e o acesso deve ser restrito.

Compreende trechos da Estação classificados como de importância extrema ou alta para a conservação (Figura 9). Foram incluídas nesta categoria parte dos trechos de Floresta Estacional Semidecidual Montana e Aluvial em seu mais alto grau de preservação, considerada como "área-fonte" para a dispersão de propágulos e enriquecimento das áreas mais degradadas no entorno (Figura 10). Também na Zona Primitiva foram incluídas as Formações Pioneiras, habitats únicos, frágeis e de extrema importância para a conservação e produção dos recursos hídricos (Figura 4).

Trata-se de uma zona dedicada à proteção integral de ecossistemas e dos recursos genéticos, com pequena ou mínima intervenção humana. As ações de manejo, quando necessárias, devem ser priorizadas nas áreas de entorno. 
IVANAUSKAS N. M.. et al. Diagnóstico e Propostas de Manejo da Vegetação da Estação Ecológica de Marília, SP, Sudeste do Brasil.

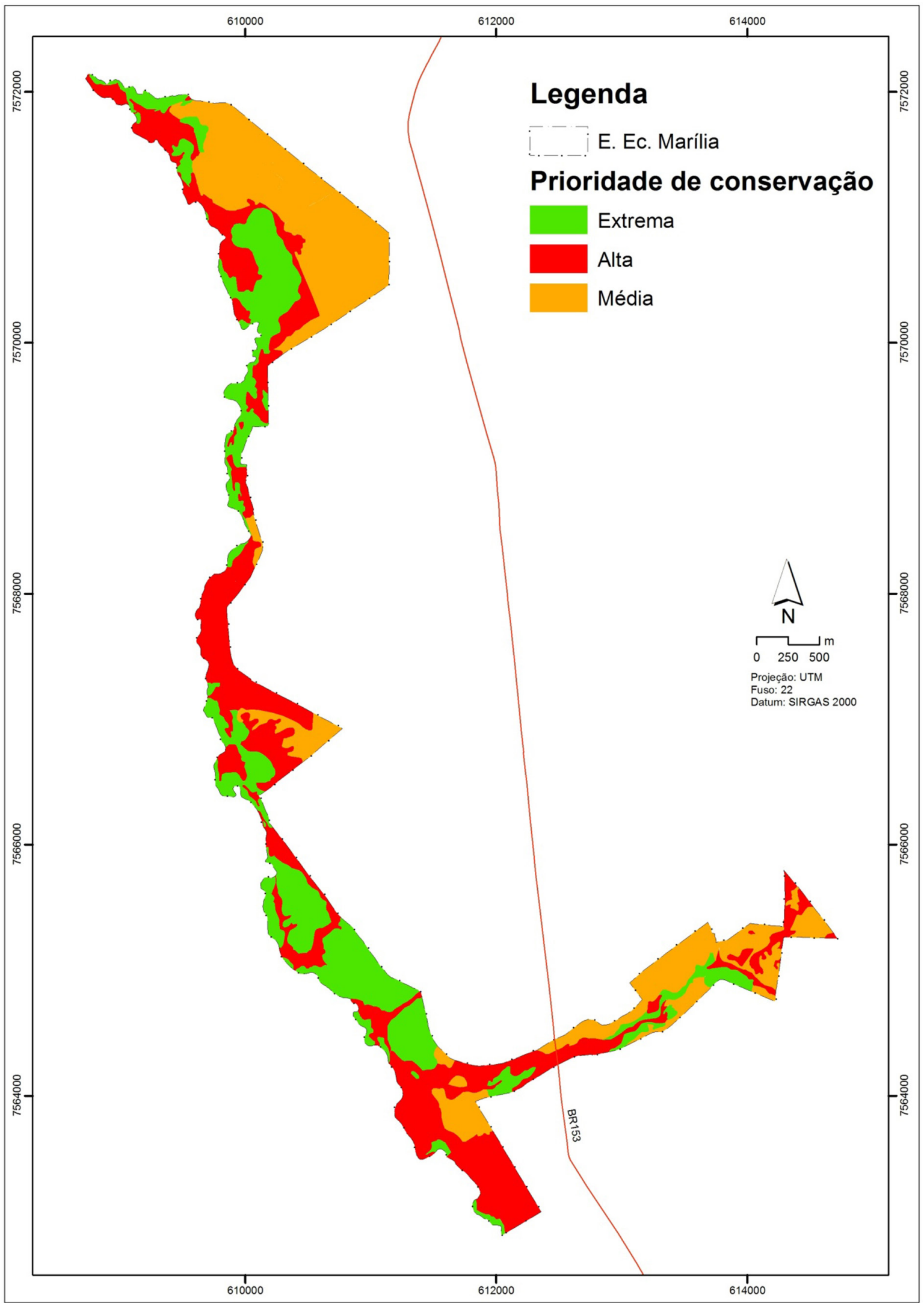

Figura 9. Áreas prioritárias para conservação na Estação Ecológica de Marília, Marília-SP.

Figure 9. Priority areas for conservation in the Marília Ecological Station, Marília-SP. 
IVANAUSKAS N. M.. et al. Diagnóstico e Propostas de Manejo da Vegetação da Estação Ecológica de Marília, SP, Sudeste do Brasil.

\subsubsection{Zona de recuperação $(349,52$ ha ou $57,6 \%$ da área)}

Áreas onde a vegetação foi consideravelmente alterada pelo homem. Trata-se de uma zona provisória, que, uma vez restaurada, será incorporada à zona primitiva. Esta zona permite a realização de pesquisas científicas até mesmo de alto impacto, desde que visem à recuperação dos ecossistemas. O uso público é permitido somente para fins educativos.

Foram consideradas como Zona de recuperação os trechos de Floresta Estacional Semidecidual muito degradados, as áreas com vegetação secundária e os reflorestamentos com nativas e exóticas (Figura 10). Por compreender zonas extensas e com diferentes graus de interferência humana, foram então delimitadas três subzonas. Para cada subzona deverão ser elaborados projetos específicos, a fim de definir o grau de intervenção e o manejo necessário para o reestabelecimento dos processos naturais de sucessão secundária e a recuperação do ecossistema.

Subzona 01 (137,88 ha ou $22,7 \%$ da área) - Trechos onde o impacto da ação humana ainda existe ou foi muito recente, com corte raso da vegetação e sua substituição por espécies exóticas. Foram englobados nesta subzona os trechos ocupados por reflorestamentos de Eucalyptus, Corymbia e Pinus.

Subzona $02(124,51$ ha ou 20,52\% da área) - Trechos de vegetação secundária, portanto locais nos quais houve intervenção humana para o uso da terra. Embora tenham sofrido corte raso no passado, atualmente encontram-se abandonadas e sujeitas aos processos de regeneração natural. De acordo com o tempo decorrido após o abandono, a extensão do dano e a resiliência do ecossistema, tais áreas podem estar em diferentes etapas do processo de sucessão. Incluiu-se nesta zona também o trecho de reflorestamento com espécies nativas, que já apresenta sub-bosque ocupado por plantas nativas.

Subzona 03 (87,13 ha ou $14,36 \%$ da área) - Refere-se às áreas onde houve impacto na vegetação natural, causado por vetores de degradação. Não se descarta aqui a possível ação humana na causa desses distúrbios, em parte ou no todo, seja pela fragmentação, ocorrência de incêndios, má conservação do solo ou pelo extrativismo seletivo. Assim, são áreas naturais onde não foi possível detectar a ocorrência de corte raso da vegetação, mas a diminuição da diversidade foi constatada em campo pelo aumento em biomassa de populações de trepadeiras nativas (espécies-problema).

Para a recuperação de qualquer uma das três subzonas propostas, a primeira ação a ser adotada é a retirada e/ou isolamento de possíveis perturbações, sem a qual as medidas posteriores serão inócuas. Tendo sido adotadas técnicas de conservação de solo que eliminem processos erosivos, a proteção contra incêndios e a erradicação das espécies invasoras, é necessário o monitoramento das áreas a serem recuperadas, a fim de verificar se a vegetação nativa conseguirá se estabelecer.

As áreas naturais indicadas na subzona 3 aparentam possuir resiliência suficiente para avançar na sucessão natural, sem necessidade de medidas suplementares de manejo. Se necessário, estudos experimentais com o intuito de avaliar diferentes técnicas de manejo de trepadeiras nativas podem ser aplicados. Também pode ser necessário o enriquecimento com algumas populações-chave. Essas espécies podem ser aquelas funcionalmente mais capazes de acelerar os processos de sucessão ou espécies prioritárias para conservação, neste caso se for constatada a baixa viabilidade das populações atuais ou para minimizar as taxas de endogamia.

Em trechos onde já existe uma comunidade arbórea, mas a diversidade está muito aquém do esperado para os tipos florestais da região (subzona 2), podem ser testadas, em caráter experimental, técnicas de enriquecimento com espécies tardias. Para o êxito dessa atividade deverá ser elaborado projeto técnico que inclua a escolha das espécies nativas regionais típicas dos estágios finais de sucessão e compatíveis com a formação vegetal original que ocupava a área a ser restaurada. As sementes necessárias para o plantio de enriquecimento devem ser obtidas em matrizes o mais próximo possível das áreas a serem restauradas, por meio da implantação de um programa de marcação de matrizes e coleta de sementes, respeitando-se o zoneamento proposto. 
IVANAUSKAS N. M.. et al. Diagnóstico e Propostas de Manejo da Vegetação da Estação Ecológica de Marília, SP, Sudeste do Brasil.

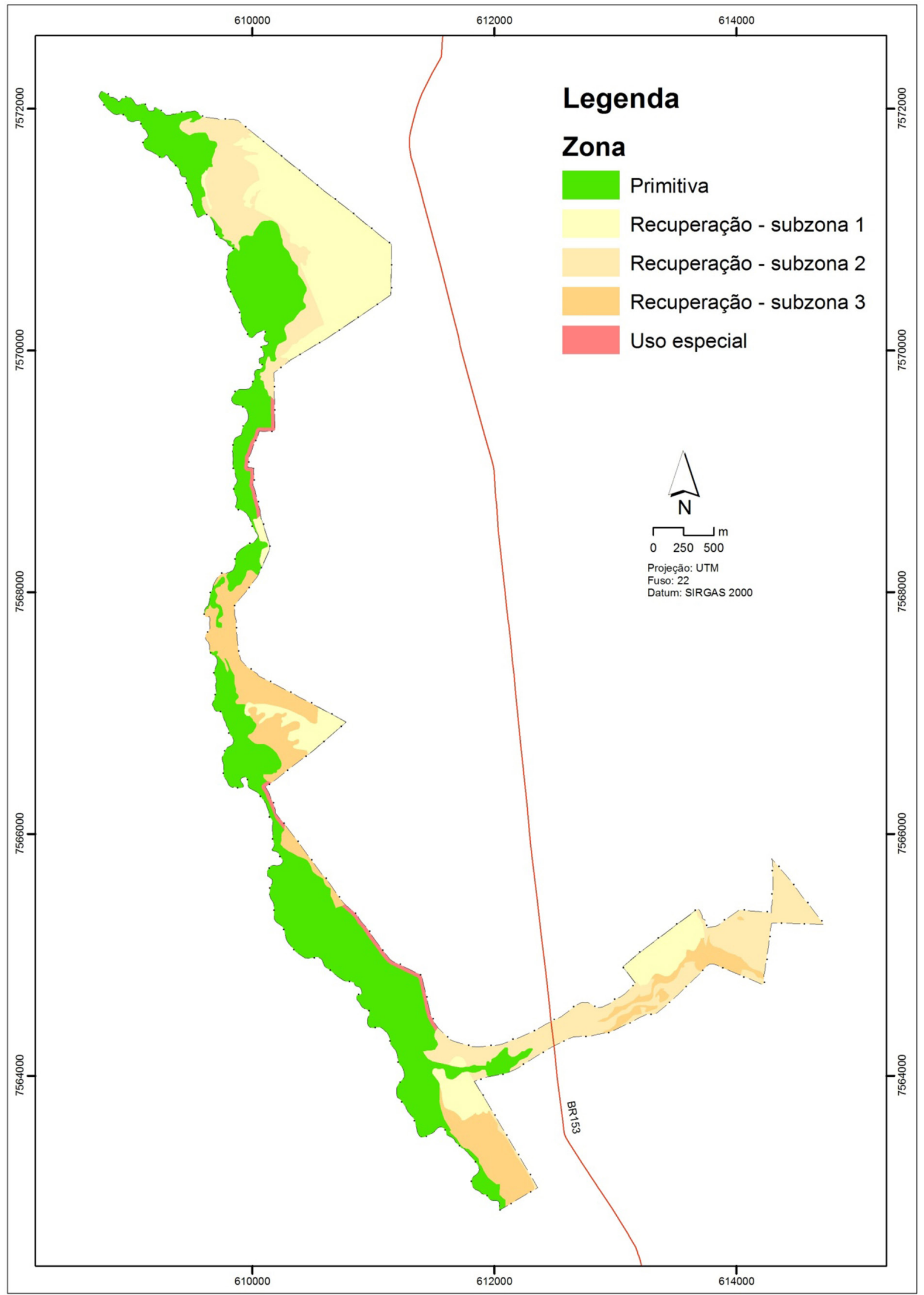

Figura 10. Proposta de zoneamento da Estação Ecológica de Marília, Marília-SP.

Figure 10. Proposal of management zones for the Marília Ecological Station, Marília-SP. 
IVANAUSKAS N. M.. et al. Diagnóstico e Propostas de Manejo da Vegetação da Estação Ecológica de Marília, SP, Sudeste do Brasil.

Mesmo para as áreas atualmente sem cobertura florestal (subzona 1), deverão ser incentivados estudos experimentais de condução da regeneração natural, desde o simples controle de gramíneas invasoras com uso de herbicidas ou por outros meios, passando pela introdução de espécies facilitadoras ou as chamadas "framework species", que devem ter mais sucesso em se estabelecer e colonizar essas áreas, desencadeando a sucessão. A formação de ilhas de diversidade nessas áreas em vez de plantio em área total também deve ser experimentada.

\subsubsection{Zona de Interferência Experimental}

É constituída por áreas naturais ou alteradas pelo homem, sujeitas a alterações definidas no Artigo $9^{\circ}$ parágrafo $4^{\circ}$ e seus incisos da Lei do SNUC, mediante o desenvolvimento de pesquisas, correspondendo ao máximo de 3\% da área total da Estação Ecológica, conforme previsto em lei. A finalidade é a de possibilitar o desenvolvimento de pesquisas científicas que exijam interferências no ecossistema natural, quer seja na sua composição de espécies, quer seja nos seus elementos abióticos (solo, microclima, água), especialmente visando à comparação com ecossistemas íntegros.

Embora esta zona deva ser incluída no Plano de Manejo, não se recomenda a definição da área nesta etapa, já que o delineamento experimental de cada projeto de pesquisa deve ser levado em consideração no cálculo da área necessária. Recomenda-se que as pesquisas experimentais destinadas ao manejo e restauração da vegetação nativa sejam realizadas na zona de recuperação.

\subsubsection{Zona de Uso Especial (8,83 ha ou 1,45\% da área)}

Contém as áreas necessárias à administração, manutenção e serviços da Unidade de Conservação (Figura 10). O objetivo de manejo desta zona é minimizar o impacto da implantação das estruturas ou efeitos de obras no ambiente natural da unidade. Constituída por áreas essenciais às operações de fiscalização e proteção da unidade, bem como à circulação de pesquisadores.

\section{CONSIDERAÇÕES FINAIS}

O conhecimento sobre a vegetação da Estação Ecológica de Marília resultante deste estudo contribui para orientar o manejo e a gestão adequada da área protegida, pois caracteriza os tipos vegetacionais presentes; registra a riqueza conhecida da flora e das espécies ameaçadas abrigadas na área; identifica as espécies exóticas e invasoras cuja presença requer providências de manejo e propõe o zoneamento e as intervenções necessárias para cumprir os objetivos de preservação da natureza e realização de pesquisas científicas definidos para esta categoria de unidade de conservação de proteção integral. Além da importância local, os dados florísticos obtidos por meio deste levantamento contribuem para ampliar os registros de ocorrência de espécies e de coletas botânicas no Estado de São Paulo, gerando e disponibilizando informações que podem incrementar bancos de dados e subsidiar ações e pesquisas diversas.

\section{AGRADECIMENTOS}

Aos pesquisadores João Batista Baitello e Osny Tadeu Aguiar pela identificação dos materiais botânicos de Lauraceae e Myrtaceae. À pesquisadora Lúcia Rossi pela revisão da grafia e sinonímia de espécies. Aos revisores anônimos que colaboraram para o aprimoramento do texto. 
IVANAUSKAS N. M.. et al. Diagnóstico e Propostas de Manejo da Vegetação da Estação Ecológica de Marília, SP, Sudeste do Brasil.

\section{REFERÊNCIAS BIBLIOGRÁFICAS}

ABREU, R.C.R.; DURIGAN, G. Changes in the plant community of a Brazilian grassland savannah after 22 years of invasion by Pinus elliottii Engelm. Plant Ecology \& Diversity, v.4, p. 269-278, 2011.

AB'SÁBER, A.N. Os domínios de natureza no Brasil: potencialidades paisagísticas. São Paulo, SP: Ateliê Editorial, 2003. 160 p.

ALVARES, C.A. et al. Köppen's climate classification map for Brazil. Meteorologische Zeitschrift, v.22, n.6, p. 711-728, 2013.

ANGIOSPERM PHYLOGENY GROUP IV - APG IV. CHASE, M.W. et al. An update of the Angiosperm Phylogeny Group classification for the orders and families of flowering plants: APG IV. Botanical Journal of the Linnean Society, v.181, n.1, p. 1-20, 2016.

BIBBY, C.J. et al. Putting biodiversity on the map: priority areas for global conservation. Cambridge, U.K.: International Council for Bird Preservation, 1992. 90p.

BORDIN, J. Fissidentaceae (Bryophyta) do Brasil. 2011. 354 f. Tese (Doutorado em Biodiversidade e Meio Ambiente), Instituto de Botânica, Secretaria do Meio Ambiente, São Paulo.

BRASIL. Lei $n^{\circ}$ 9.985, de 18 de julho de 2000. Regulamenta o art. 225, § 1o, incisos I, II, III e VII da Constituição Federal, institui o Sistema Nacional de Unidades de Conservação da Natureza e dá outras providências. Diário Oficial da União, Seção 1, 19 jul. 2000, p.01.

CARVALHO, M.L.S. Estudos taxonômicos em Mayacaceae Kunth. 2007. 78 f. Dissertação (Mestrado em Ciências Biológicas - Biologia Vegetal) - Universidade Estadual Paulista, Rio Claro.

CENTRO DE PESQUISAS METEOROLÓGICAS E CLIMÁTICAS APLICADAS A AGRICULTURA CEPAGRI. Clima dos Municípios Paulistas: Marília. Disponível em: <http://www.cpa.unicamp.br/outrasinformacoes/clima_muni_107.html>. Acesso em: 01 set. 2014.

DURIGAN, G. Florística, fitossociologia e produção de folhedo em matas ciliares da região oeste do Estado de São Paulo. 1994. 149 f. Tese (Doutorado em Biologia Vegetal) - Universidade Estadual de Campinas, Campinas.

.; LEITÃO FILHO, H.F. Florística e fitossociologia de matas ciliares do oeste paulista. Revista do Instituto Florestal, v.7, p.197-239, 1995.

.; et al. Produção de folhedo em matas ciliares na região oeste do Estado de São Paulo. Revista do Instituto Florestal, São Paulo, v. 8, n.2, p. 187-199, 1996.

.; PAGANO, S.N. Aspectos da ciclagem de nutrientes em matas ciliares do oeste do Estado de São Paulo, Brasil. In: RODRIGUES, R.R.; LEITÃO FILHO, H.F. (Org.). Matas ciliares: conservação e recuperação. 1ed. São Paulo: EDUSP/FAPESP, 2000. p. 109-123.

DURIGAN, G. et al. Control of invasive plants: ecological and socioeconomic criteria for the decision making process. Natureza \& Conservação, v. 11, p. 23-30, 2013.

ENGEL, V.L. et al. Ecologia de lianas. IPEF, v.32, n.12, p.43-64, 1997.

ETTORI, L.C. et al. Variabilidade genética em duas populações de Cordia trichotoma. Revista do Instituto Florestal, v.11, n.2, p.179-187, 1999. 
IVANAUSKAS N. M.. et al. Diagnóstico e Propostas de Manejo da Vegetação da Estação Ecológica de Marília, SP, Sudeste do Brasil.

FARAH, F.T. et al. Forest destructuring as revealed by the temporal dynamics of fundamental species - Case study of Santa Genebra Forest in Brazil. Ecological Indicators, v.37, p. 40-44, 2014.

FORZZA, R.C. et al. Lista de Espécies da Flora do Brasil. Rio de Janeiro: Jardim Botânico, 2014. Disponível em: <http://floradobrasil.jbrj.gov.br/>. Acesso em: 3 mar. 2014.

GALANTE, M.L.V. et al. Roteiro Metodológico de Planejamento: Parque Nacional, Reserva Biológica, Estação Ecológica. Brasília, DF: Edições IBAMA, 2002. 136 p.

GALINDO-LEAL, C.; CÂMARA, I.G. Mata Atlântica: biodiversidade, ameaças e perspectivas. São Paulo, SP: Fundação SOS Mata Atlântica \& Conservação Internacional, 2005. 472 p.

GARRIDO, L.M.A.G. et al. Efeitos do sombreamento no crescimento da aroeira - Myracrodruon urundeuva Fr. All. Revista do Instituto Florestal, v. 9, n.1, p. 47-56, 1997.

HORTON, R.E. An approach toward a physical interpretation of infiltration capacity. Soil Science Society of America Proc., v. 5, p. 399-417, 1940.

INSTITUTO BRASILEIRO DE GEOGRAFIA E ESTATÍSTICA- IBGE. Sistema Fitogeográfico. In: Manuais técnicos em geociências. Rio de Janeiro, RJ: IBGE, 2012.

Folhas topográficas Getulina (SF-22-X-C-VI-3) e Marília (SF-22-Z-A-III-1). Rio de Janeiro, RJ: IBGE. 1983. Escala 1:50.000.

INCT - HERBÁRIO VIRTUAL DA FLORA E DOS FUNGOS. Disponível em: <http://splink.cria.org.br/>. Acesso em: 30 out. 2014.

INTERNATIONAL UNION FOR CONSERVATION OF NATURE - IUCN. Lista vermelha de espécies ameaçadas de extinção. 2014. Disponível em: <http://www.iucnredlist.org>. Acesso em: 28 ago. 2014.

INSTITUTO HÓRUS DE DESENVOLVIMENTO E CONSERVAÇÃO AMBIENTAL. Base de dados nacional de espécies exóticas invasoras, I3N Brasil. Florianópolis. Disponível em: $<$ http://i3n.institutohorus. org.br>. Acesso em: 16 fev. 2014.

IVANAUSKAS, N.M. et al. Levantamento florístico de um trecho de Floresta Atlântica em Pariquera-Açu, SP. Naturalia, v. 26, p. 97-129, 2001.

IVANAUSKAS, N.M. et al. Vegetação da Estação Ecológica de Ribeirão Preto: caracterização e subsídios ao plano de manejo. IF Série Registros, v. 45, p. 1-47, 2011.

KEEL,S.; SAYRE, R.; SEDAGHATKISH, G. Levantamentos da Vegetação e Espécies de Plantas. In: SAYRE, R. et al. Natureza em Foco: Avaliação Ecológica Rápida. The Nature Conservancy, Arlington, Virginia, USA. 2003.

KOTCHETKOFF-HENRIQUES, O. Caracterização da vegetação natural em Ribeirão Preto, SP: Bases para conservação. 2003. 221 f. Tese (Doutorado em Ciências - Biologia Comparada) - Faculdade de Filosofia, Ciências e Letras, Universidade de São Paulo, Ribeirão Preto.

KRONKA, F.J.N. et al. Inventário florestal da vegetação natural do estado de São Paulo. São Paulo: Secretaria do Meio Ambiente; Instituto Florestal; Imprensa Oficial, 2005. 200 p.

LACLAU, P. La conservación de los recursos naturales renovables y el hombre en la selva Paranaense. Boletín Técnico Fundación Vida Silvestre Argentina, v.20, p. 1-139, 1994.

LUEDER, D.R. Serial photographic interpretation, principles and applications. New York: MacGrawHill, 1959. 462 p. 
IVANAUSKAS N. M.. et al. Diagnóstico e Propostas de Manejo da Vegetação da Estação Ecológica de Marília, SP, Sudeste do Brasil.

MAGNAGO, L.F. et al. Os processos e estágios sucessionais da Mata Atlântica como referência para a restauração florestal. In: MARTINS, S.V. (Org.). Restauração Ecológica de Ecossistemas Degradados. 2ed. Viçosa: Editora UFV, 2015, p. 70-101.

MARTINELLI, G.; MORAES, M.A. (Orgs.). Livro vermelho da flora do Brasil. Rio de Janeiro, RJ: Andrea Jakobsson: Instituto de Pesquisas Jardim Botânico do Rio de Janeiro, 2013. 1.100 p.

MATTOS, I.F.A. A fisionomia vegetal e suas relações com o meio físico na definição das unidades de paisagem na alta bacia do rio Turvo-SP. 1994. 141 f. Dissertação (Mestrado em Geografia Física) Departamento de Geografia, Faculdade de Filosofia Letras e Ciências Humanas, Universidade de São Paulo, São Paulo.

MIRANDA, M.J. et al. Clima dos Municípios Paulistas: a classificação climática de Koeppen para o Estado de São Paulo. CEPAGRI. Disponível em: <http://www.cpa.unicamp.br/outras-informacoes/clima-dosmunicipios-paulistas.html>. Acesso em: 01 set. 2014.

MOREIRA, J.R.; PIOVEZAN, U. Conceitos de manejo de fauna, manejo de população problema e o exemplo da capivara. In: NEGRÃO, M.G.S.P. (Ed.). Documentos.. Embrapa Recursos Genéticos e Biotecnologia, Brasília, v.155, p.1-23, 2005.

MORELLATO, L.P.C. Características dos padrões fenológicos em florestas estacionais neotropicais. In: CLAUDINO-SALES, V. (Org.). Ecossistemas brasileiros: manejo e conservação. Fortaleza, CE: Expressão Gráfica, 2003. p. 299-304.

NALON, M.A. et al. Quantificação da vegetação natural remanescente para os municípios do Estado de São Paulo - Legenda IBGE - RADAM - 2009. Sistema de informações florestais do Estado de São Paulo. Disponível em: <http://www.iflorestal.sp.gov.br/sifesp/creditos.html>. Acesso em: 25 abr. 2013.

SÃO PAULO (Estado). Resolução SMA nº 057, de 05 de junho de 2016. Publica a segunda revisão da lista oficial das espécies da flora ameaçadas de extinção no Estado de São Paulo. 2016. Diário Oficial do Estado de São Paulo, 07 jun. 2016. Seção I, p. 69-71.

. (Estado). Decreto n ${ }^{0}$ 56.615, de 28-12-2010. Cria a Estação Ecológica de Marília na área que compõe a Estação Experimental de Marília, em terras que estão sob posse e domínio da Fazenda Pública do Estado de São Paulo, e dá providências correlatas. 2010. Diário Oficial do Estado de São Paulo, 29 dez. 2010. Seção I, p. 9.

SPURR, S.H. Photogrammetry and photo-interpretation. New York: Ronald Press, 1960. 472 p.

VELOSO, H.P. Sistema fitogeográfico. In: IBGE. Manual técnico da vegetação brasileira. Série Manuais Técnicos em Geociências, v.1, p. 8-38, 1992.

; GÓES-FILHO, L. Fitogeografia brasileira: classificação fisionômico-ecológica da vegetação neotropical. Boletim técnico do Projeto RADAMBRASIL, Série vegetação, v.1, p.1-80, 1982.

ZALBA, S.M. Introdução às invasões biológicas: conceitos e definições. In: MATTHEWS, S. América do Sul invadida: a crescente ameaça das espécies exóticas invasoras. Argentina: Programa Global de Espécies Invasoras, 2005. p. 4-5.

ZILLER, S.R. Plantas exóticas invasoras: a ameaça da contaminação biológica. Ciência Hoje, v. 178, p. 77 79, 2001. 
IVANAUSKAS N. M.. et al. Diagnóstico e Propostas de Manejo da Vegetação da Estação Ecológica de Marília, SP, Sudeste do Brasil.






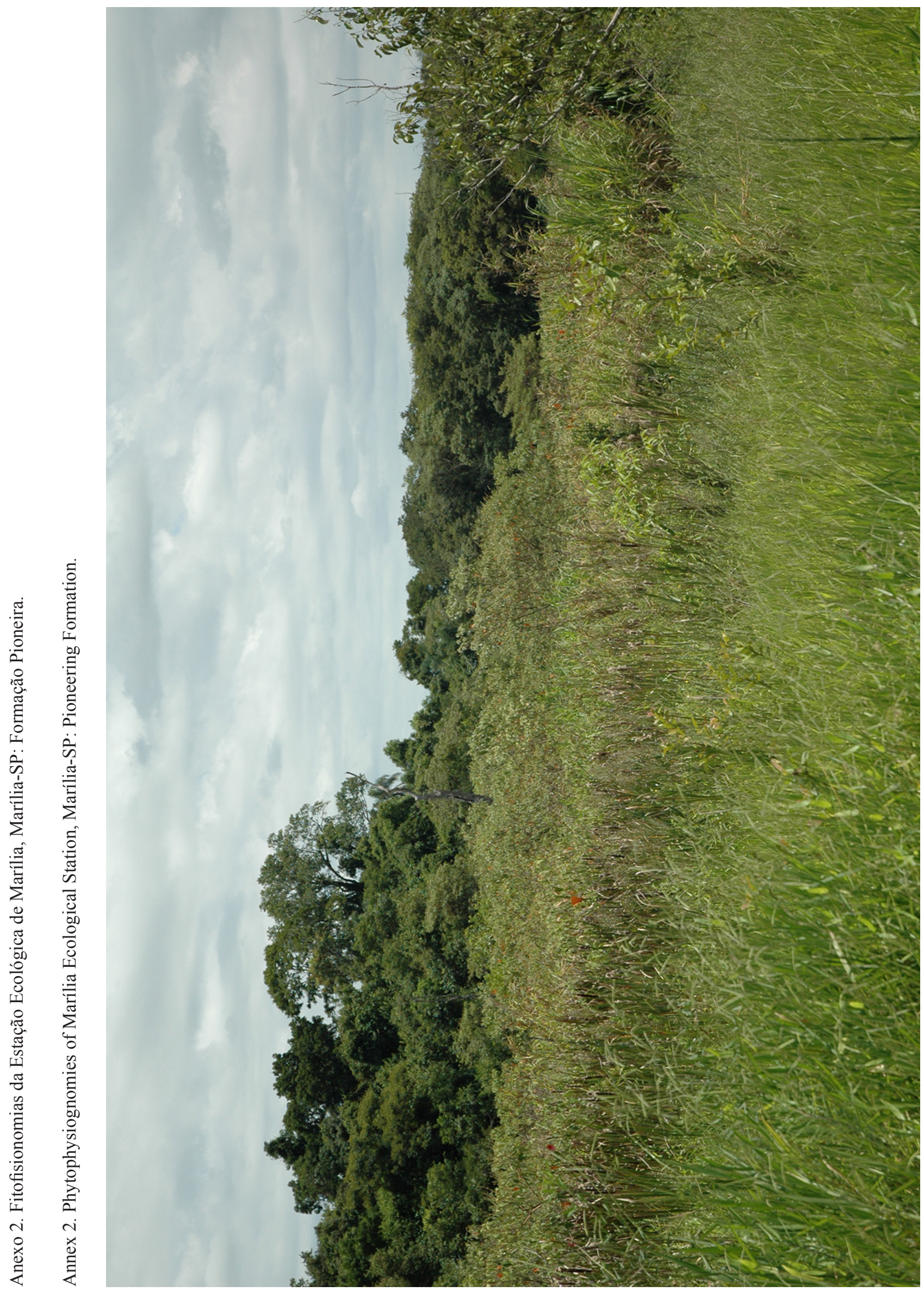


IVANAUSKAS N. M.. et al. Diagnóstico e Propostas de Manejo da Vegetação da Estação Ecológica de Marília, SP, Sudeste do Brasil.

Anexo 3. Trepadeiras registradas na Estação Ecológica de Marília, Marília-SP. A) Prestonia coalita; B) Prestonia tomentosa; C) Amphilophium paniculatum; D) Arrabidaea craterophora; E) Arrabidaea florida; F) Cuspidaria convoluta; G) Stizophyllum perforatum; H) Janusia janusioides; I) Gouania inornata. (Fotos: Renata Udulutsch).

Annex 3. Vines recorded in the Marília Ecological Station, Marília-SP. A) Prestonia coalita; B) Prestonia tomentosa; C) Amphilophium paniculatum; D) Arrabidaea craterophora; E) Arrabidaea florida; F) Cuspidaria convoluta; G) Stizophyllum perforatum; H) Janusia janusioides; I) Gouania inornata. (Photos: Renata Udulutsch).
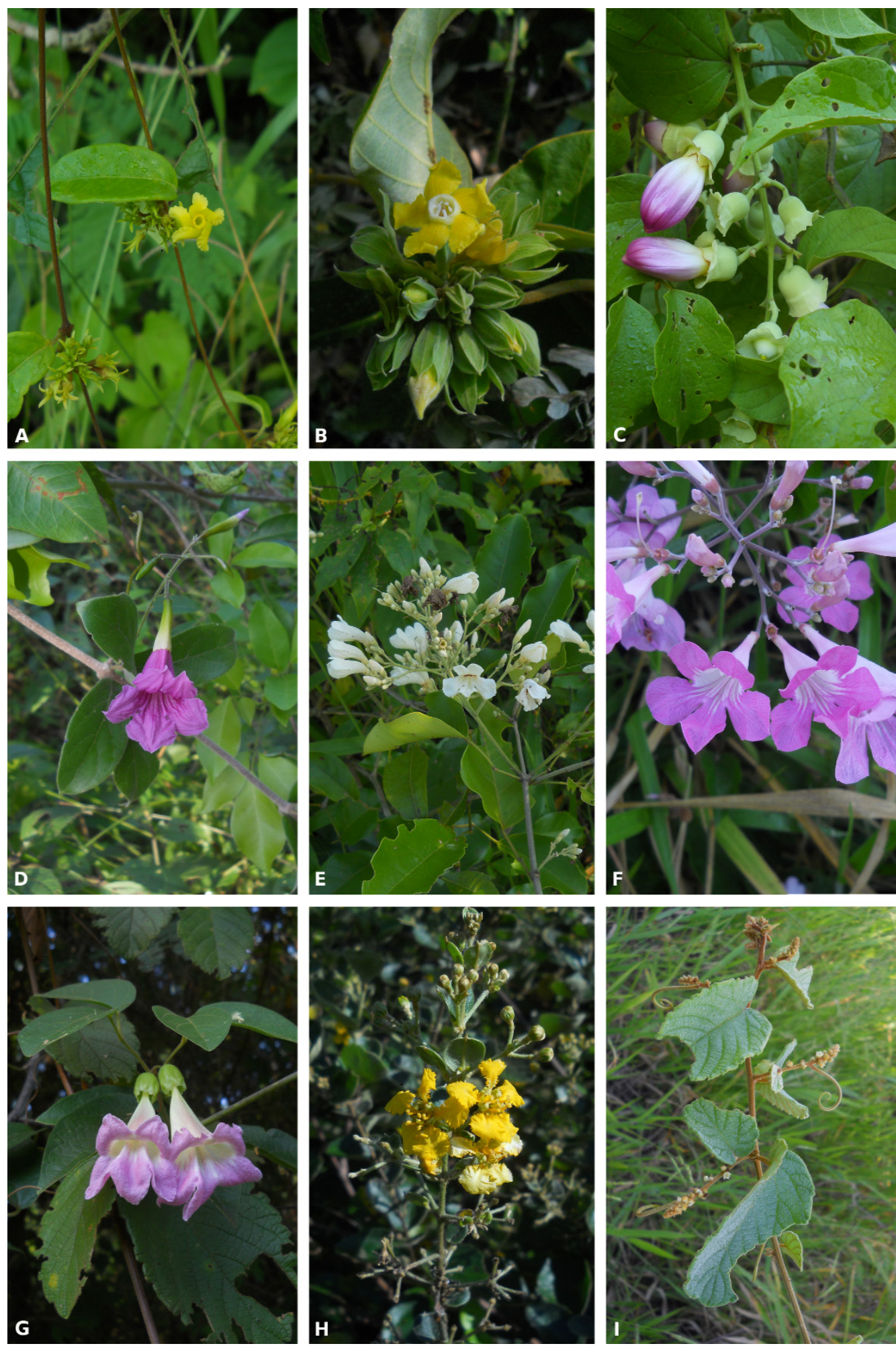